Mississippi State University

Scholars Junction

$5-4-2018$

\title{
Landowner willingness to participate in a grassland conservation program facilitating ecosystem services
}

Tharaka A. Jayalath

Follow this and additional works at: https://scholarsjunction.msstate.edu/td

\section{Recommended Citation}

Jayalath, Tharaka A., "Landowner willingness to participate in a grassland conservation program facilitating ecosystem services" (2018). Theses and Dissertations. 5057.

https://scholarsjunction.msstate.edu/td/5057

This Graduate Thesis - Open Access is brought to you for free and open access by the Theses and Dissertations at Scholars Junction. It has been accepted for inclusion in Theses and Dissertations by an authorized administrator of Scholars Junction. For more information, please contact scholcomm@msstate.libanswers.com. 
Landowner willingness to participate in a grassland conservation program facilitating ecosystem services

By

Tharaka A. Jayalath

\author{
A Thesis \\ Submitted to the Faculty of \\ Mississippi State University \\ in Partial Fulfillment of the Requirements \\ for the Degree of Master of Science \\ in Forest Resources \\ in the Department of Forestry
}

Mississippi State, Mississippi

May 2018 


\section{Copyright by}

Tharaka A. Jayalath 
Landowner willingness to participate in a grassland conservation program facilitating ecosystem services

By

Tharaka A. Jayalath

Approved:

Robert K. Grala

(Major Professor)

David L. Evans

(Minor Professor)

Stephen C. Grado

(Committee Member)

Andrew W. Ezell

(Graduate Coordinator)

\section{George M. Hopper}

Dean

College of Forest Resources 
Name: Tharaka A. Jayalath

Date of Degree: May 4, 2018

Institution: Mississippi State University

Major Field: Forest Resources

Committee Chair: Robert K. Grala

Title of Study: Landowner willingness to participate in a grassland conservation program facilitating ecosystem services

Pages in Study 73

Candidate for Degree of Master of Science

Grasslands provide a number of goods and services that benefit humans, but only a few have a market value. Despite the benefits provided, native grasslands continue to be degraded. Lack of a proper valuation, including a monetary value of nonmarket goods and services, has become one of the factors contributing to this trend. The objective of this research was to quantify the cost of increasing provision of ecosystem services from grasslands in the Gulf Coastal Plains and Ozarks Landscape Conservation Cooperative geographic area of the United States and identify effective landowner engagement strategies for their provision. A contingent valuation method (CVM) was used to estimate landowner willingness to accept (WTA) compensation in exchange for implementing management practices preserving grassland ecosystems. Results will be helpful in quantifying future funding levels necessary for implementation of coordinated conservation activities in grasslands and other ecosystems and developing conservation programs in the United States and other countries. 


\section{DEDICATION}

I dedicate my work to my loving parents who brought me up to be who I am today and who provided me with continuous support and have always been there for me. 


\section{ACKNOWLEDGEMENTS}

My thesis research would not be possible without the immense support from my Major Professor, Dr. Robert K. Grala. I'm very grateful for his countless hours of reading, encouraging, and most of all his patience throughout the entire process. I also wish to thank my Graduate Committee members who were more than generous with their expertise and precious time. Thank you Dr. Stephen Grado and Dr. David Evans for agreeing to serve on my committee. I also extend my sincere thanks to the College of Forest Resources, Forest and Wildlife Research Center, and the Department of Forestry at Mississippi State University for financial support throughout my degree program. Finally, I thank my loving wife for her continuous support and being there for me through the hard times. 


\section{TABLE OF CONTENTS}

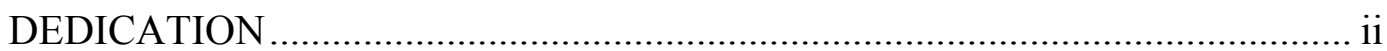

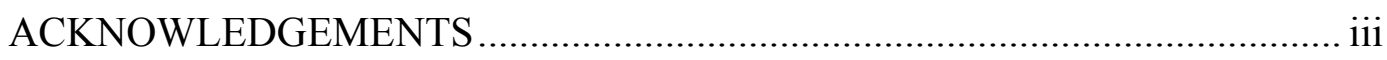

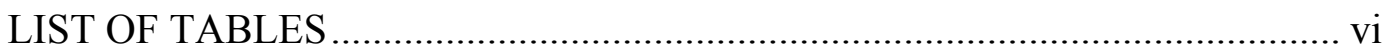

LIST OF FIGURES ……………………………................................... vii

\section{CHAPTER}

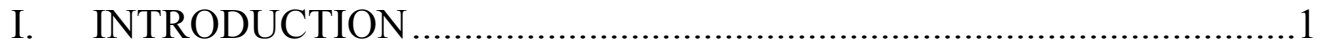

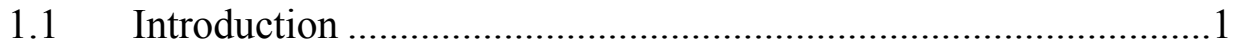

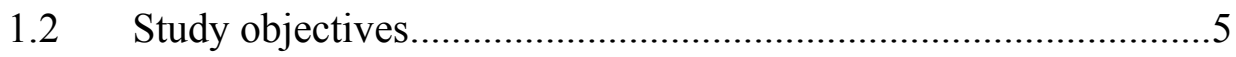

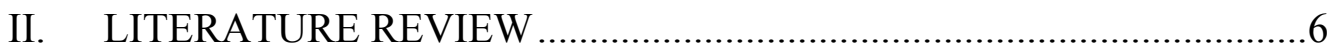

2.1 Classification of grasslands and their distribution in the United States.....................................................................................

2.2 Market goods and services produced by grassland ecosystems ....9

2.3 Nonmarket goods and services associated with grasslands.........10

$2.4 \quad$ Valuation of nonmarket goods and services.................................12

III. MATERIALS AND METHOD ………………………………….......

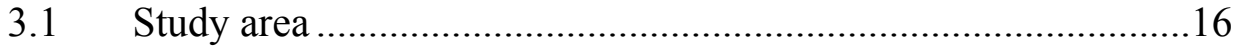

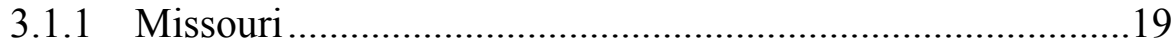

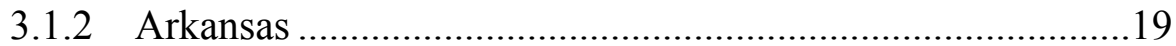

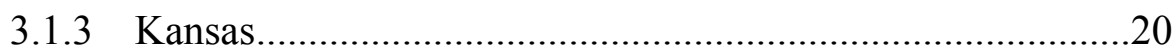

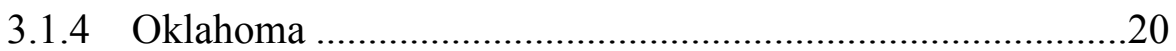

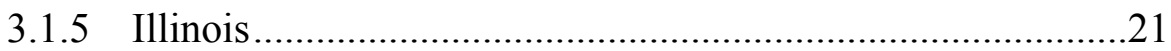

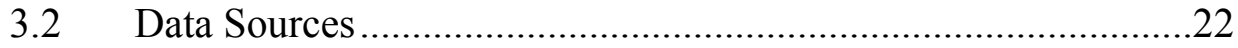

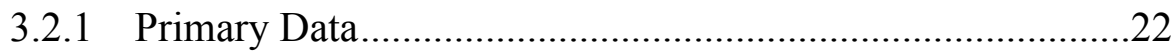

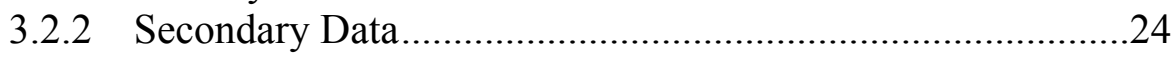

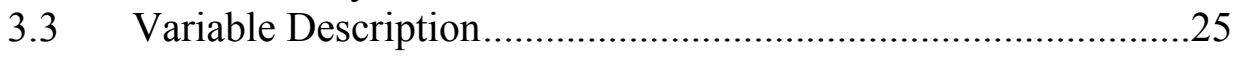

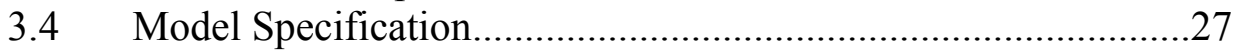

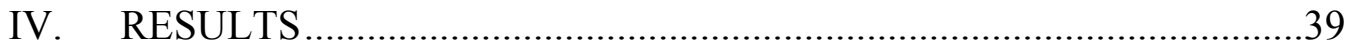


4.1 Landowner socio-demographic characteristics ........................39

4.2 Land ownership characteristics .........................................42

4.3 Concern with environmental issues ..........................................43

4.4 Satisfaction towards existing financial and technical assistance programs ........................................................................44

4.5 Determinants of willingness to accept compensation ................45

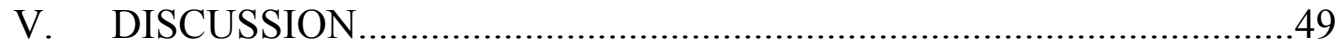

VI. CONCLUSION AND POLICY IMPLICATIONS ...............................60 


\section{LIST OF TABLES}

3.1 Description of the variables used in the probit model to estimate monetary compensation amounts for participation in a hypothetical grassland conservation program facilitating provision of ecosystem services.

4.1 Landowner membership in organizations based on responses to a mail survey conducted in 2016 in the Interior Highlands geographic area of Gulf Coastal Plain and Ozarks Land Conservation Cooperative, United States.

4.2 Landowner contact frequency with organizations providing technical and financial assistance based on responses to a mail survey conducted in 2016 in the Interior Highlands geographic area of Gulf Coastal Plain and Ozarks Land Conservation Cooperative, United States

4.3 Priority of reasons for landownership based on responses to a mail survey conducted in 2016 in the Interior Highlands geographic area of Gulf Coastal Plain and Ozarks Land Conservation Cooperative, United States.

4.4 Landowner concern with environmental issues based on responses to a mail survey conducted in 2016 in the Interior Highlands geographic area of Gulf Coastal Plain and Ozarks Land Conservation Cooperative, United States.

4.5 Factors associated with landowner willingness to enroll in a conservation program based on responses to a mail survey conducted in 2016 in the Interior Highlands geographic area of Gulf Coastal Plain and Ozarks Land Conservation Cooperative, United States. ....48 


\section{LIST OF FIGURES}

2.1 Historical geographic distribution of two major grassland biomes in the contiguous United States: the Central Plains and Western Grasslands (Conner et al. 2001). Data sources: Environmental Protection Agency (EPA 2016) ........................................................8

3.1 Study area within Gulf Coastal Plains and Ozarks Land Conservation Cooperative in the United States (GCPO 2009)...............................18

3.2 Distribution of grassland and pasture and/or hay land in Gulf Coastal Plains and Ozarks Landscape Conservation Cooperative in the United States (GCPO LCC) (Homer et al. 2015 .......................................22

3.3 Compensating variation (CV) in a case of welfare loss incurred by a landowner who implemented grassland management restrictions required by a conservation program. 


\section{INTRODUCTION}

\subsection{Introduction}

Grasslands are natural ecological communities dominated by herbaceous and shrub vegetation and maintained by fire, grazing, low percipitation, and/or freezing temperatures (White et al. 2000). Three main types of grassland ecosystems found in the U.S. include short-grass, mixed-grass, and tallgrass ecosystems commonly referred to as prairies. A short-grass ecosystem predominantly occurs in the more arid areas of the Great Plains towards the West, whereas the other two ecosystems occur on the eastern part of the Great Plains (Dissanayake and Ando 2014). Most prairie ecosystems are found west of Mississippi River, but some native grasslands are also scattered across midwestern and southeastern states. In 2012, both grasslands with native vegetation, native grasslands used for grazing, and pasture lands accounted for 655.57 million acres, which represented $28.47 \%$ of the total land area in the U.S. including Alaska (USDA ERS 2017) and mostly under private landownership (Conner et al. 2001). Thus, vast areas of grassland ecosystems are affected by various biophysical drivers and human impacts (Sneath 1998, Solbrig 1993). As a result, human activities are a part of these semi-natural ecosystems and alteration of human activities might cause further changes to grassland ecosystems (Rashford et al. 2011).

Grasslands represent unique ecosystems that provide humans with numerous ecological, social, and economic benefits, often extending beyond a grassland's geographical location (Conner et al. 2001). Goods and services, such as meat, milk, wool, leather, and recreational activities are some of most valuable products and services 
currently produced by grasslands (White et al. 2000). Grasslands located west of Mississippi River provide $90.00 \%$ of feed needed for sheep, beef cattle, domestic goats, and horses (Conner et al. 2001). In 1999, the monetary value of livestock feed provided by grasslands ranged from $\$ 57.00$ to $\$ 167.00$ (1999 U.S. dollars) per cow for a typical pasture operation in states west of the Mississippi River and represented a major cost saving to ranchers utilizing these lands (USDA ERS 2000).

In terms of recreational activities associated with grasslands, their monetary value has also been substantial. For example, in 2011 the U.S. Fish and Wildlife Service estimated that 3.12 million recreationists spent, on average, $\$ 350.00$ per person per year on hunting activities related to bird species such as pheasant (Phasianus colchicus), quail (Coturnix coturnix) and prairie chicken (Tympanuchus cupido) whose main habitats are grassland ecosystems (USDI and USDC 2011). Therefore, pasture lands and grasslands are economically valuable ecosystems and have been playing an important role in local and regional economies. For example, a total economic contribution of wildlife recreational activities on all land types in the southeastern United States in was 53.90 billion in 2006 (Munn et al. 2010).

Grassland ecosystems, however, also provide numerous benefits not traded in the markets. While these benefits do not have prices attached, they have been increasingly recognized for their contribution to an improved quality of human life (Inman and McLeod 2002, Loomis et al. 2000a, Power 1996, Rudzitis 1993). For example, grasslands have been identified as a source of many vital nonmarket ecosystem services such as atmospheric carbon dioxide $\left(\mathrm{CO}_{2}\right)$ sequestration, soil conservation, maintenance of wildlife habitat, promotion of genetic diversity, and weather amelioration (Conner et al. 
2001, Sala and Paruelo 1997). Grasslands are capable of absorbing relatively large amounts of $\mathrm{CO}_{2}$, both in a form of soil organic and inorganic carbon (Conner et al. 2001). This is because they cover approximately half of the world's land area and account for more than a $33.00 \%$ of above and below ground carbon (C) reserves (Allen-Diaz 1995). Grasslands also play an important role in limiting organic soil loss which, on average, is 10 to 60 times greater on continuously cropped lands than perennial grasslands, assuming the same watershed conditions (Krishna et al. 1988). An example of another ecologically and economically important ecosystem service provision is wildlife habitat. For instance, the Prairie Potholes region in the north-central U.S. contains wetland grassland ecosystems provides habitat for approximately 50.00 to $80.00 \%$ of the continent's duck population (Reynolds 2005, Batt et al. 1989, Cowardin et al. 1983). These ecosystems also provide breeding habitat for more than half of the grassland bird species in North America (Knopf 1995). However, most of these ecosystem services are public goods, with no market value, and consequently neglected in private land-use decisions. Thus, failure to account for a potential monetary value in land-use decisions might lead to their inefficient production and allocation, and a further degradation of grassland ecosystems.

Despite numerous benefits, grasslands continue to be cleared and degraded at a high rate mainly due to habitat fragmentation, undesirable habitat changes due to fire exclusion, improper grazing management as well as encroachment of nonnative and invasive plant species (Dissanayake and Ando 2014, Conner et al. 2001). A higher rate of deforestation in the eastern United States, fragmentation and replacement of grassland vegetation with intensive agricultural production, and large-scale deterioration of rangelands in the western United States resulted in an overall loss of native grasslands in 
North America (Dissanayake and Ando 2014). From 1700 to 1992, almost 50.00\% of native grasslands were converted to other land uses with a majority going to crop production (Ramankutty and Foley 1999). Most native prairie ecosystems were converted during that time to other land uses in an irreversible manner (Conner et al. 2001), whereas most remaining native grassland ecosystems have continuously been degraded to the point where they can no longer provide the same level of ecological, social, and economic benefits (Conner et al. 2001). Therefore, there is an urgent need to preserve grassland ecosystems through restoration and conservation efforts to maintain and potentially increase their ecological and economic potential.

Trends in grassland conversion have been heavily influenced by economic factors. An important driver of future grassland conversion will be determined by whether the current trend of a relatively higher profitability of alternative land uses, such as crop production, will continue (Conner et al. 2001). Many environmental scientists indicated that improper valuation of nonmarket ecosystem services, or lack of such assessments, is one of the factors contributing to deforestation and forest degradation (Gregersen et al. 1995). Similarly, grassland owners are typically not compensated for providing nonmarket ecosystem services and thus they usually do not account for them in land-use decisions. As a result, a lack of information on monetary value of nonmarket ecosystem services provided by grasslands, and their conversion to alternative land uses, have heavily contributed to grassland degradation (Martin and Wilsey 2006, Fletcher and Koford 2002, Hatch et al. 1999). Thus, quantifying monetary values associated with grassland ecosystem services will be crucial for developing more effective policies and programs promoting grassland conservation and creating effective incentive programs for 
private landowners to increase the provision of ecosystem services from grassland ecosystems.

\section{$1.2 \quad$ Study objectives}

Landowner management decisions related to management of their grasslands and pasture lands can have substantial impacts on land-based provisioning of ecosystem services (Conner et al. 2001). Therefore, the overall study objective was to determine landowner willingness to engage in land management facilitating sustained provision of ecosystem services from private grasslands. The study had the following specific objectives:

- Determine factors affecting willingness of landowners in the Interior Highland Region of the Gulf Coastal Plains and Ozarks Landscape Conservation Cooperative (GCPO LCC), covering the states of Missouri, Arkansas, Oklahoma, Illinois, Kansas, and Kentucky, to participate in a grassland conservation program.

- Quantify a monetary cost of increasing provision of nonmarket ecosystem services from grassland ecosystems by computing compensation amounts required by private landowners to implement conservation management practices. 


\section{CHAPTER II}

\section{LITERATURE REVIEW}

\subsection{Classification of grasslands and their distribution in the United States}

Historic, native prairies in the U.S. spread through portions of six major regions. From East to West, they include Central Lowlands, Coastal Plains, Desert Southwest, Great Plains, Great Basin, and Central Valley of California. Broadly these grasslands can be categorized into two major biomes, Central Plains and Western Grasslands, which are separated from North and South by the Rocky Mountains (Figure 2.1; Ricketts et al. 1999, Omernik 1987, Kuchler 1975). These two grassland biomes differ greatly in terms of terrain configuration, climate, predominant land use, and landownership patterns (Conner et al. 2001).

The Central Plains grassland biome represents the most extensive historical grasslands in North America covering 688.00 million acres prior to European settlement (Ricketts et al. 1999). From west to east of this region, annual precipitation gradually increases and correspondingly, grassland ecosystems shift from short-grass prairies to mixed-grass prairies, then to tallgrass prairies, and finally to a savanna (Conner et al. 2001). These four types of prairie ecosystems are identified as the Physical Provinces of the Central Plains: shortgrass prairies of the Great Plains, mixed-grass prairies of the Great Plains, tallgrass prairies of the Central Lowlands and Coastal Plains, and savannas of the Central Lowlands and Coastal Plains, respectively (Ricketts et al. 1999). The 
majority of grasslands in the Central Plains are dominated by non-federal landownerships where privately-owned grassland ecosystems covered 541.00 million acres during presettlement within 13 states west of Mississippi River which include Colorado, Iowa, Kansas, Minnesota, Missouri, Montana, Nebraska, New Mexico, North Dakota, Oklahoma, South Dakota, Texas, and Wyoming (Conner et al. 2001).

The Western Grasslands represent a prominent biome west of the Rocky Mountains and east of the Cascades consisting of shrub-dominated ecosystems as well as sparsely vegetated desert terrain (Ricketts et al. 1999, Omernik 1987, Kuchler 1975, Stoddart and Smith 1955). Western Grasslands lie in two major physical provinces, the Great Basin and Desert Southwest. The Mediterranean Grasslands ecoregion in California's Central Valley is also part of the Western Grasslands (Conner et al. 2001). Most of these Western Grasslands are classified as rangelands characterized by low and inconsistent precipitation, rough topography, poor drainage, and cold temperatures which make them unsuitable for agricultural cultivation (Stoddart and Smith 1955).

Climate is the most important factor in the development of natural grasslands (Lauenroth 1979). In the United States, grasslands are prominent in areas experiencing an annual precipitation of 10 to 40 inches, both in wet and dry seasons, and having a mean annual temperature of 32 to $79^{0} \mathrm{~F}$ with seasonal fluctuations (Lieth 1975). Even though these climatic factors facilitate tree growth within prairie ecosystems, variability in precipitation prevents full forest development (Conner et al. 2001). However, increasing pressure from human population growth, associated with increased per capita income and a greater demand for land and commodities, has increased the threat to traditional uses of grassland ecosystems (Conner et al. 2001). 


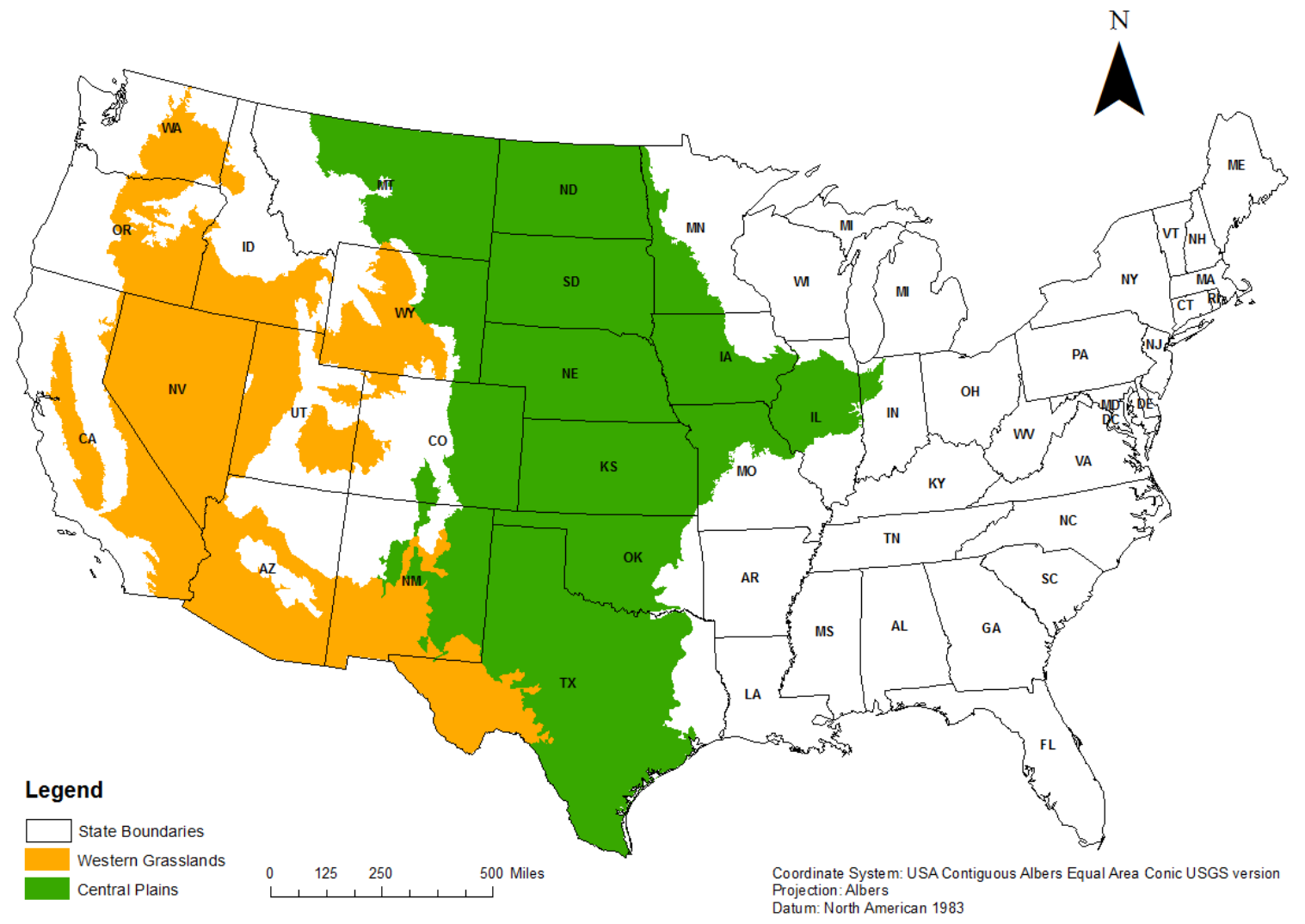

Figure 2.1 Historical geographic distribution of two major grassland biomes in the contiguous United States: the Central Plains and Western Grasslands (Conner et al. 2001). Data source: Environmental Protection Agency (EPA 2016)

Apart from the climatically-controlled native prairie ecosystems, most currently existing grasslands are categorized as derived grassland ecosystems created as a product of intensive human management which includes hay and pasture lands. There are two types of derived grasslands that were initially categorized as successional grasslands and agricultural grasslands (Lauenroth 1979) and this classification has been used until the present. Successional grasslands have developed as a result of forest and/or shrub removal and subsequent maintenance of land in a pasture condition through a 
combination of burning, mowing, and grazing (Lauenroth 1979). Agricultural grasslands have been created as a result of intensive agricultural practices such as cultivating and planting genetically modified or improved grass species and maintaining them by irrigation and mineral fertilization (Lauenroth 1979). Despite the fact that a recent literature on the classification of derived grasslands is limited, some studies reported that substantial areas of native forests, shrub lands, and woodlands were converted to derived grasslands (DeFries et al. 1999), whereas 82.00 to $99.00 \%$ of tallgrass ecosystems were altered for agricultural purposes (Samson and Knopf 1996).

\subsection{Market goods and services produced by grassland ecosystems}

Grassland ecosystems provide both economic and ecological benefits to landowners and the general public. Forage for grazing animals plays an important role in terms of monetary returns from grassland ecosystems and cost savings (Conner et al. 2001). In 1999, pasture costs of for livestock accounted for 14.00 to $33.00 \%$ of the total operating costs of $\$ 408.00$ to $\$ 486.00$ per bred cow (1999 U.S. dollars) for a typical cowcalf operation in states west of the Mississippi River (USDA ERS 2000). The sheep industry is considered the next most important rangeland-dependent livestock industry in the U.S. In total, $86.00 \%$ of the breeding sheep production is located in 22 contiguous states west of the Mississippi River (Conner et al. 2001) and privately-owned nonirrigated grazing lands are the primary source sheep and beef cattle forage (Gee and Madsen 1988). Other types of livestock, including horses and goats, depend upon grasslands for feed to differing degrees but the amount of forage consumed is relatively small in comparison to sheep and cattle (Conner et al. 2001). Thus, grassland ecosystems provide numerous agricultural and livestock goods that have a market value. 
In addition to forage production, recreational activities related to grassland-based fishing and wildlife hunting also account for considerable amount of expenditures and contributions to local, state, and national economies. For example, in 2011 the U.S. Fish and Wildlife Service reported there were more than 90.00 million fishing and wildlife hunting participants who generated $\$ 145.00$ billion in expenditures (USDI and USDC 2012) associated with outdoor recreational activities on both private and public lands, including grasslands. This represented a $\$ 40.00$ billion increase between 1996 and 2011 (USDI and USDC 2012). While this data did not differentiate between recreational activities related to different land types (e.g., lakes, forests, wetlands, grasslands, rivers), they indicated that the large number of individuals participated in the hunting activities related to bird species such as common pheasant (Phasianus colchicus), common quail (Coturnix coturnix) and prairie chicken (Tympanuchus cupido) whose main habitats are grassland ecosystems.

\subsection{Nonmarket goods and services associated with grasslands}

North American native grassland ecosystems represent substantial area of biotic diversity compared to other terrestrial ecosystems by providing habitat for numerous plant and animal species. For example, an inventory conducted by Armstrong et al. (1986) indicated that of 138 mammals in the north-central prairie states, $11.60 \%$ were only found in prairie ecosystems within the Great Plains (Benedict et al. 1996). Studies by Knopf (1995) and Biddy et al. (1992) determined that of 29 widespread grassland bird species, nine species were classified as only originating from grassland ecosystems. Furthermore, among 124 species of reptiles and amphibians recorded in the Central Plains, 15 species originated primarily in these prairies (Corn and Peterson 1996). 
In addition to small mammals, grassland ecosystems provide habitat for freeranging herbivores. For example, there were approximately 45 million American bison (Bison bison) and pronghorn antelope (Antilocapra americana) in North American native grasslands in the $17^{\text {th }}$ century. Bison were primarily predominant the Central Plains and pronghorn antelope ranged much further into the arid Western Grasslands (Shelford 1963). Due to extended herds of grazing animals, grassland ecosystems were also associated with substantial populations of gray wolves (Canis lupus), which are now mostly extinct in grassland areas (Licht 1997). There was also a population of five billion prairie dogs (Cynomus spp.) during the 1870s in short- and mixed-grass prairies (Miller et al. 1994). Prairie dog grazing and burrowing habits influenced nutrient cycling and resulted in a preferable vegetation composition of the surrounding prairie habitat. For example, grassland bird diversity and numbers increased in areas where prairie dog colonies existed (Agnew et al. 1986), because birds such as burrowing owl (Athene cunicularia), mountain plover (Charadrius montanus), and horned lark (Eremophila alpestris) tend to prefer grassland vegetation modified by prairie dogs (Baker et al. 2013). As a result, prairie dogs are known as a "keystone" species for maintaining biotic diversity of prairie ecosystems (Miller et al. 1994).

As the aforementioned and many other grassland ecosystem services are not traded in the marketplace, they are often neglected in land-use decisions. Therefore, there is a need to quantify them in monetary terms to enable an adequate comparison between the cost of their provision and the value of benefits derived by society. As a result, a monetary valuation of grassland ecosystem services will lead to more informed land-use decisions and will have the potential to aid in increasing the provision of these services. 


\section{$2.4 \quad$ Valuation of nonmarket goods and services}

Understanding the monetary value of ecosystem services provided by grassland ecosystems is important for making more informed land-use decisions and ensuring a sufficient provision of these services in the future (Matthews et al. 2000). However, most ecosystem services are public goods and their monetary value cannot be determined by observing market transactions because they are not traded in markets (Inman and McLeod 2002, Loomis et al. 2000b, Power 1996, Rudzitis 1993). However, it is important to overcome this barrier to better understand the value of grassland ecosystem services to the society as well as being able to determine a cost of preserving these services to make them available.

Numerous valuation techniques have been developed to quantify the monetary value of nonmarket ecosystem services (Farber et al. 2002). Broadly, they can be categorized into two groups: revealed and stated preference methods. Revealed preferences methods are used to estimate the value of a nonmarket good or service based on human preferences related to a market good (e.g., house values) that has a direct relationship with a nonmarket good or service (Freeman et al. 2014). These techniques include the travel cost method (TCM), originally proposed by Clawson in 1959 (Swinton et al. 2007, Carr and Mendelsohn 2003) and the hedonic pricing method (HPM), introduced by Ridker and Henning in 1967 (Kong et al. 2007, Tyrväinen and Miettinen 2000). In contrast, stated preference methods quantify the value of nonmarket environmental goods and services based on individual responses to a hypothetical scenario illustrating a change in a nonmarket good or service availability or quality. 
The contingent valuation method (CVM) is the most common stated preference valuation technique. The CVM was originally proposed by Ciriacy-Wantrup (1947) to quantify the monetary value of public benefits resulting from soil erosion control. However, the first empirical study utilizing the CVM was conducted to estimate the monetary value of benefits associated with goose (Anser spp. and Branta spp.) hunting through a survey of goose hunters (Davis 1963). The CVM has become more popular compared to revealed preference methods due to its ability to capture non-use values that include option, existence, and bequest values. (Smith 1993). In 1989, the Exxon Valdez accidentally spilled 11 million gallons of oil into Alaska's pristine Prince William Sound (Duffield 1997). This incident was recorded as the first case where a nonuse value was estimated using CVM to quantify a monetary value of damages (Carson et al. 2003). Currently, CVM is widely used in environmental economics to estimate nonmarket use values of environmental resources (e.g., Choe et al. 1996, Loomis and DuVair 1993), nonuse values (e.g., Walsh et al. 1984, Brookshire et al. 1983), and both (e.g., Niklitschek and Leon, 1996, Desvousges et al. 1993).

The CVM can be used to estimate individual willingness to pay (WTP) and willingness to accept (WTA) a monetary amount for changes in quality or quantity of an environmental good (Haab and McConnell 2002). Even though some studies have criticized CVM applications due to its various limitations, researchers determined that CVM was a reliable method for undertaking nonmarket valuation estimates if a study was properly designed and implemented (Venkatachalam 2004). Furthermore, its attention given to the conceptual foundations and reliable estimation techniques for nonuse values has increased, leading to its more comprehensive applications (Carson et al. 2003). 
Most studies criticizing CVM have based their criticism on its validity and reliability (Arrow et al. 1993, Freeman 1993, Smith 1993). Validity refers to the degree to which CVM measures the true economic value (a Hicksian consumer surplus measure) through a hypothetical scenario (Freeman 1993). Reliability refers to the extent to which the variance between WTP and WTA amounts is due to random sources (Mitchell and Carson 1989). Numerous inconsistences and biases can impact CVM validity and reliability and include WTA/WTP disparity (Cummings et al. 1986), embedding or scope effects (Bateman et al. 1997), question order bias (Mitchell and Carson 1989), starting point bias (Walsh et al. 1984), hypothetical bias (Neill et al. 1994), and strategic bias (Carson et al. 2001). Therefore, these limitations can be addressed by properly planning, implementing, and analyzing CVM study data (Venkatachalam 2004). The National Oceanic Atmospheric and Administration (NOAA) Panel on CVM evaluated its role in estimating nonuse values and concluded that CVM's WTP approach could be used effectively under their guidelines which reduced uncertainty related to CVM validity and reliability (Arrow et al. 1993). Despite certain limitations, CVM is currently the most commonly used method to derive information on value of nonmarket goods and services that could not be observed by using stated preference techniques.

The majority of existing nonmarket valuation studies on conservation and restoration of ecosystem services are related to wetland ecosystem conservation and restoration (Boyer and Polasky 2004, Woodward and Wui 2001, Heimlich et al. 1998), forest ecosystem conservation and restoration (Lehtonen et al. 2003, Adger et al. 1995), protection of endangered avian species (Bowles 1998, Loomis and Ekstrand 1997), and recreation such as hunting (Horne and Petäjistö 2003, Hanley et al. 2002, Boxall et al. 
1996). However, there have been a relatively small number of studies quantifying a monetary value of ecosystem services associated with grassland ecosystems. One study was conducted by Dissanayake and Ando (2014) to estimate a monetary value of grassland restoration using a choice experiment survey and determining WTP for different attributes of restored grasslands in Illinois. The authors determined that WTP was highly dependent on presence of nearby grassland, plant and animal species richness, population density measured by number of species, and presence of endangered species. Earnhart (2006) used both contingent valuation and conjoint analysis to estimate a monetary value of aesthetic benefits provided by a prairie open space adjacent to residential locations in Kansas and found that a presence of a permanently protected prairie was associated with a $5.00 \%$ increase in a house value. Both studies focused on valuation of grassland ecosystem services from a perspective of beneficiaries and, in both cases, they estimated WTP. However, these studies did not include grassland owners who are ecosystem service providers and whose land-use decisions might affect the quantity and quality of ecosystem services provided by these ecosystems in the future. These landowners might need to be compensated to ensure that ecosystem services are produced in sufficient amounts and, therefore, there is a need to determine compensation levels they might require to produce these services at levels preferred by the public. 


\section{CHAPTER III \\ MATERIALS AND METHOD}

\subsection{Study area}

This study was conducted in the Interior Highlands region which is the one of five geographical units of the GCPO LCC (Figure 3.1). The GCPO LCC is one of 22 national land conservation networks in the United States and covers 180.00 million acres across 12 states from Oklahoma and Texas in the western United States to Alabama, Georgia, and Florida in the southeastern United States (GCPO 2009). The Interior Highlands region includes southern Missouri and northern Arkansas as well as small portions of Illinois, Kansas, and Oklahoma (GCPO 2009). This region represents the only highland in mid-continental North America and is the only notable topographic relief between the Appalachian and the Rocky Mountains. The hills and valleys of this region are dominated by forests, which comprise nearly $60.00 \%$ of the land cover, whereas grassland habitats account for $29.00 \%$ of the area and represent the largest grassland cover in the GCPO LCC geographic area (GCPO 2009). Glades, prairies, savannas, and woodlands still remaining in the region provide key habitats for many high priority species that do not exist outside of the region [e.g., Bell's vireo (Vireo bellii pusillus), Bewick's wren (Thryomanes bewickii), collared lizard (Crotaphytus collaris), scrubland tiger beetle (Cicindelinae), western diamondback rattlesnake (Crotalus atrox), and ornate box turtle (Terrapene ornata ornata)] (GCPO 2009). As indicated by 2011 national land cover data 
assembled by Multi-Resolution Land Characteristics Consortium (Homer et al. 2015), the Interior Highland region covered a total of 10.10 million acres of both grasslands/herbaceous lands and pasture/hay lands and extended over the parts of six states in the GCPO LCC. Grasslands/herbaceous lands are typically dominated by plant grasses and forbs. In rare cases, herbaceous cover might be less than $25.00 \%$ but still exceeds the combined cover of the woody species (Homer et al. 2015). While these areas are not subjected to intensive management, they are often utilized for grazing (Homer et al. 2015). Pasture/hay lands, on the other hand, represent areas consisting of grasses, legumes, or grass-legume mixtures planted for livestock grazing or production of seed or hay crops. These areas are typically under intensive management (Homer et al. 2015). 


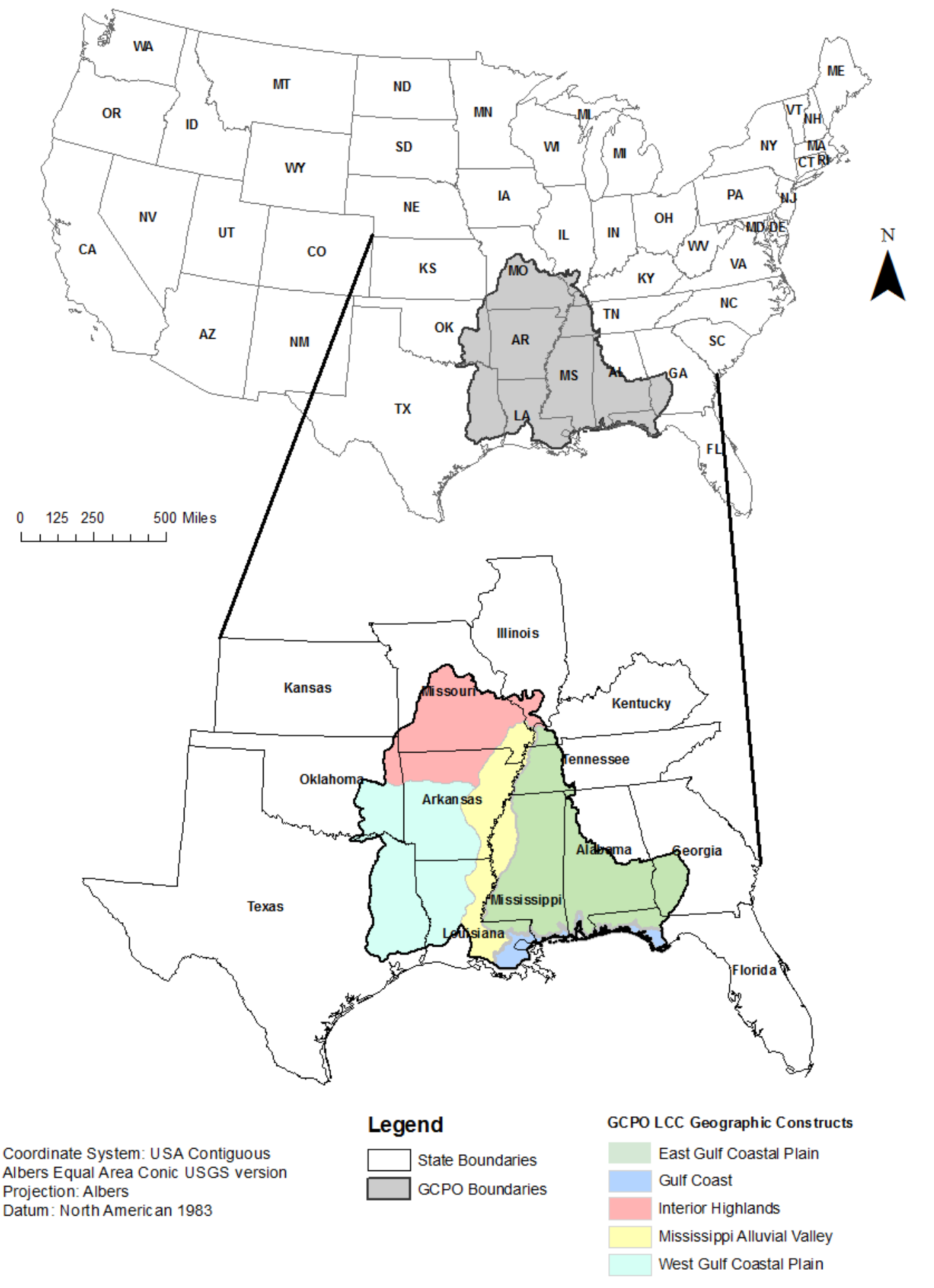

Figure 3.1 Study area within Gulf Coastal Plains and Ozarks Land Conservation Cooperative in the United States (GCPO 2009). 


\subsubsection{Missouri}

In the early the1800s, Missouri's native grasslands extended across approximately 15.30 million acres representing $19.30 \%$ of tallgrass ecosystems which was the largest grassland ecosystem area outside of Texas (Kuchler 1975). According to the National Resource Inventory conducted by USDA Natural Resources Conservation Service (NRCS), the decline in native grasslands has been notable in Missouri and the state experienced a 14.00\% loss in area from 1982 to 1997 (NRCS 1997). Meanwhile, there was no significant change in pasture lands (NRCS 1997). Most native prairies were converted to crop production or non-native forage grasslands to support the ranching industry (Conner et al. 2001). Even though they are economically important, most current grasslands lack natural diversity to provide the same level of ecosystem services as original native prairie ecosystems (Conner et al. 2001). In 2011, both native grasslands which were not under intensive management, and grasslands under intensive management such as pasture lands, covered 13.90 million acres and represented $31.00 \%$ of the total land area in Missouri (Figure 3.2, Homer et al. 2015).

\subsubsection{Arkansas}

Arkansas's tallgrass savanna ecosystems covered 160,000 acres before European settlement (Kuchler 1975). A relatively small area of original native prairie ecosystems coupled with a higher population growth has resulted in a comparatively small area of remaining native grasslands in Arkansas. According to USDA Forest Service's data related to major land uses, the state experienced a $31.90 \%$ decline in native grasslands from 1982 to 1997 (Conner et al. 2001). Meanwhile, pasture land decreased by $5.00 \%$ during the same time period. In 2011, both native and intensively managed grasslands 
covered approximately 5.30 million acres and represented $15.60 \%$ of the total land area in Arkansas (Figure 3.2, Homer et al. 2015).

\subsubsection{Kansas}

Kansas has the most diverse prairie ecosystems in the study area comprised of tall-grass savannas, tall-grass prairies, northern mixed-grass prairies, southern mixedgrass prairies, and short-grass prairies (Egbert et al. 1997). Collectively, these prairie ecosystems covered 47.20 million acres prior to European settlement (Kuchler 1975). West of the Rocky Mountains, scarce rainfall supported short-grass prairies; whereas a sufficient rainfall in the central part of the state supported mixed-grass prairies (Coupland 1958). However, prairie ecosystems in Kansas have undergone a substantial degradation resulting in a 9.70\% reduction in area between 1982 and 1997 (Conner et al. 2001). During the same time, pasture lands recorded a growth of $7.50 \%$ (NRCS 1997). In 2011, both native and intensively managed grasslands covered 24.00 million acres and represented $45.70 \%$ of the total land area in Kansas (Figure 3.2, Homer et al. 2015).

\subsubsection{Oklahoma}

Oklahoma had 37.80 million acres covered with tall-grass ecosystems in the early 1800s (Kuchler 1975). According USDA Forest Service's data on major land uses, there was a 5.90\% decline in native grasslands from 1982 to 1997 (Conner et al. 2001). During the same time period, there was a growth in pasture lands of $10.40 \%$ (NRCS 1997). In 2011, both native and intensively managed grasslands accounted for 21.30 million acres and represented $47.60 \%$ of the total land area in Oklahoma (Figure 3.2, Homer et al. 2015). 


\subsubsection{Illinois}

In the early the $1800 \mathrm{~s}, 20$ million acres of native prairie were recorded in Illinois and consisted primarily of tall-grass ecosystems (Kuchler 1975). Most prairie lands were converted to agricultural use because they consisted of deep and rich soils (Conner et al. 2001). Increasing urban development across the state further contributed to the loss of native prairies (Packard and Mutel 1997). In 1998, the Illinois Natural Areas Inventory was conducted by the USDA and estimated that only 2,400 acres of high-quality prairies existed on 250 sites. This amount represented less than $0.01 \%$ of the original prairie acreage. In 2011, native grasslands and intensively managed grasslands accounted for 3.40 million acres and represented $9.30 \%$ of the total land area in Illinois (Figure 3.2, Homer et al. 2015). 


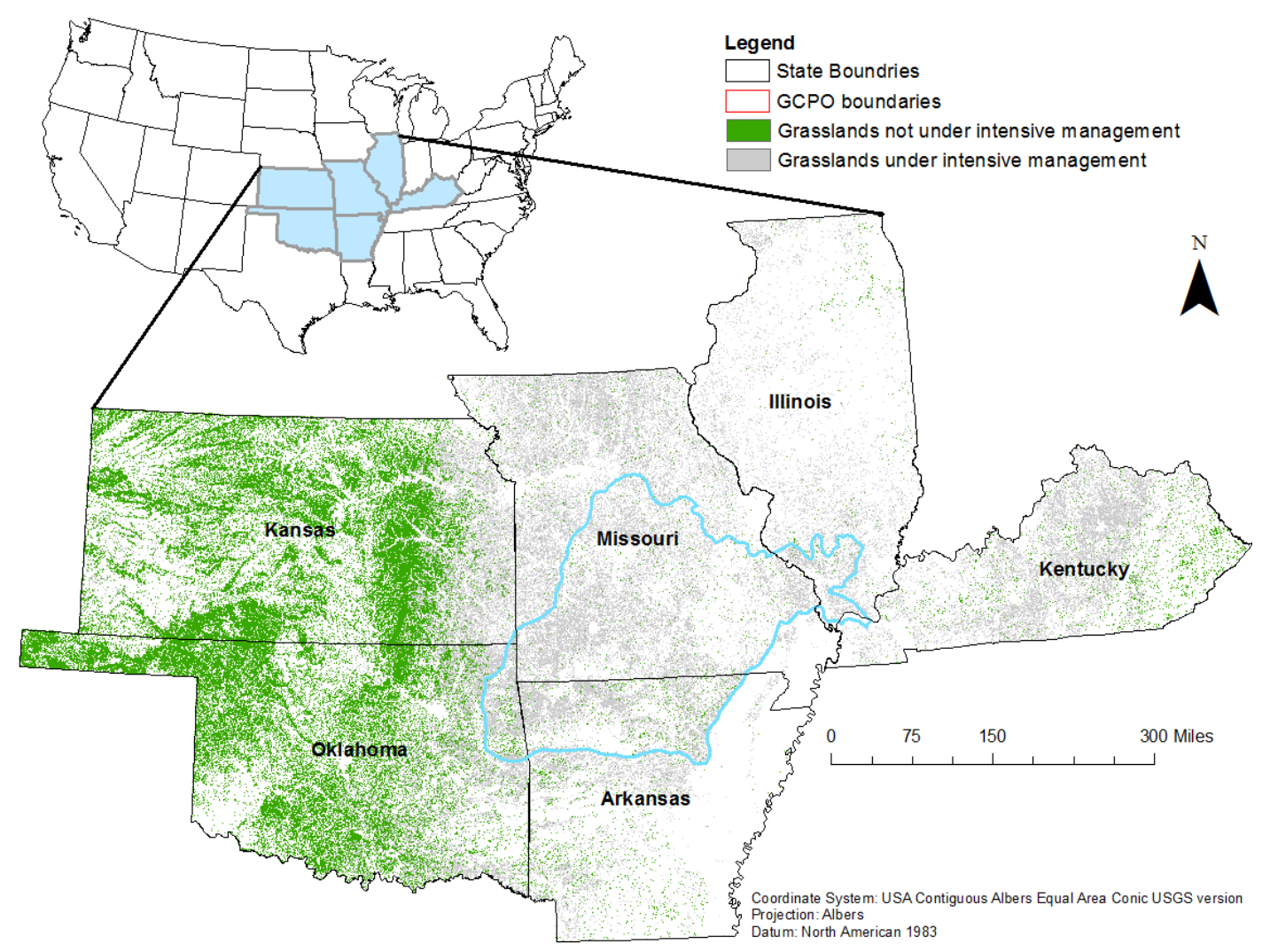

Figure 3.2 Distribution of grassland and pasture and/or hay land in Gulf Coastal Plains and Ozarks Landscape Conservation Cooperative in the United States (GCPO LCC) (Homer et al. 2015.

\subsection{Data Sources}

\subsubsection{Primary Data}

Primary data were collected through a mail survey of forest and agricultural landowners in the Interior Highlands of the GCPO LCC. The sample included 2,000 randomly selected landowners with at least 10 acres of forest and/or agricultural land. Mailing addresses were obtained from a commercial mailing list provider based on the largest land parcel location in the Interior Highlands by forest and agricultural land-use classification. The survey implementation followed an adaptation of Dillman's total design method and involved five mail contacts: 1) an initial letter explaining study objectives, 2) a letter with a questionnaire, 3) a thank you/ reminder postcard, 4) a follow- 
up letter with a questionnaire, and 5) and a final follow-up letter with the questionnaire (Dillman 2011). The survey collected information on ownership characteristics, landownership objectives, frequency of landowner contacts with organizations offering assistance to landowners, satisfaction levels with financial and technical programs, landowner willingness to enroll into a conservation program facilitating the provision of ecosystem services, and landowner socio-demographic characteristics.

The questionnaire also included a hypothetical contingent valuation scenario to determine landowner willingness to enroll into a grassland conservation program facilitating ecosystem services and subsequently quantify a monetary value of preserving these services. In the hypothetical valuation scenario, landowners were asked to assume they owned a 50-acre parcel of grassland used for grazing and hay production. Then, landowners were presented with an opportunity to participate in a new conservation program hypothetically administrated by the USDA. Under the conservation program agreement, landowners were required to implement practices preserving their grasslands over a 10-year period in exchange for an annual payment. During the contract, landowners were not allowed to convert their grasslands to other uses such as crops and urban development. Also, their management practices would have to be restricted during a nesting season to protect declining bird species. However, they were allowed to use their grasslands for grazing and hay production, and seed harvest. Landowners were also allowed to place fire breaks and implement fire to rehabilitate their grasslands. It was explained that these grassland management practices would enhance the provision of ecosystem services. After a description of the conservation program and its requirements, the questionnaire included the following contingent valuation question: 
"Would you enroll your 50-acre grassland tract into the conservation program described above if you were offered an annual payment of $\$$ per acre for the duration of 10 year contract?" This question included a randomly assigned payment amount and a landowner was offered one of three responses: yes, no, and unsure.

\subsubsection{Secondary Data}

Secondary data included geospatial information related to proximity to environmental amenities and urbanized areas, and a percentage change in grassland area. Secondary data were obtained from publicly available sources including the United States Geological Survey (USGS, USGS 2000), United States Census Bureau, and MultiResolution Land Characteristics Consortium (MRLC). Vector data representing locations of national, state, and local parks and urbanized areas were obtained as shapefiles from USGS to determine a distance between the centroid of a postal zip code area in which a land parcel was located and the nearest geographic feature. The protected areas operated by Department of Interior National Park Service were considered as the national parks, whereas protected areas managed at state government level were categorized as state parks. An another group of protected areas, including regional and local parks that were managed by local governments, was categorized as local parks and consisted of local parks located beyong municipal boundaries. Furthermore, distance between a land parcel and two types of the urban areas as defined by U.S. Census Bureau. Urban areas with population of 50,000 or more people were considere as urbanized areas, whereas urban areas with population of least 2,500 but less than 50,000 people were considered as urban clusters. The proximity analysis was completed using an ArcGIS geo-processing tool called Generate Near Table. An assessment of percentage change in grassland area was 
based on the set of two raster data layers of National Land Cover Data (NLCD) for the years 1992 and 2011. Layers represented area of grasslands/herbaceous and pasture/hay lands and were obtained from the MRLC. The grassland area percentage change was quantified at a postal code area using an ArcGIS spatial analyst tool called Tabulate Area.

\subsection{Variable Description}

Landowner willingness to enroll in a grassland conservation program (ENROLL) served as a dependent variable in the model and represented a referendum-format choice question regarding landowner willingness to enroll into a proposed conservation program at an offered annual payment where a landowner had three response options: yes, no, and unsure. Unsure responses were removed from further analysis, whereas the remaining landowner responses were coded as a binary variable where 1 indicated a landowner was willing to enroll into the proposed conservation program and 0 indicated a landowner was unwilling to enroll.

Landowner decision to enroll into a conservation program was modeled based on a set of independent variables representing a bid level, landowner socio-demographic characteristics, land physical attributes, and landowner attitudes and previous experiences. A bid level (BID) represented a monetary compensation offered to landowners for enrolling into the proposed grassland conservation program and was expressed as an annual payment in U.S. dollars (\$) per acre per year for a 10-year contract period. A landowner was offered one compensation amount that was randomly selected from 10 possible compensation levels: $\$ 1, \$ 2, \$ 3, \$ 5, \$ 10, \$ 20, \$ 40, \$ 80, \$ 160$, and \$320. Landowner socio-demographics characteristics included age (AGE), gender (GENDER), and before-taxes household income (INCOME), whereas land physical 
attributes included the area of owned agricultural (AGLAND) and forest land (FORLAND).

Landownership objectives originally included 14 ownership categories ranging from production of traditional and non-traditional forest and agricultural products to family tradition and provision of ecosystem services. A factor analysis with a principal component extraction and varimax rotation was implemented to identify ownership goals with similar patterns (Costello and Osborne 2005). Four factors were obtained which explained cumulatively $62.00 \%$ of the variance in the original landownership goals. Four attitudinal variables, each with a highest factor loading, were selected as proxy variables for their respective factors. The importance of protecting endangered species (OBJ_ENDANG) served as a proxy variable for the factor representing ecosystem services; profitable working lands for traditional forest, range, and agricultural products (OBJ_PROFIT) represented profit-based reasons; family tradition (OBJ_FAMI_TRAD) denoted family tradition and legacy ownership objectives, and fee-based recreation (OBJ_REC_INV) represented recreational and long-term investment objectives. Landownership variables were originally recorded as categorical variables measured on a rising 1-5 Likert priority scale and were: 1 - not a priority, 2 - low priority, 3 - medium priority, 4 - high priority, and 5 - essential. Each variable was then recoded to a dummy variable based on their mean values (Hardy 1993). If a landowner's original priority ranking of their selected ownership reason was above a mean Likert score, it was coded as 1 (priority) and, if it was below a mean, it was coded as 0 (not a priority).

Frequency of contacts between landowner and organizations was measured in terms of 10 organizations providing technical and financial assistance. Three factors, 
explaining cumulatively $65.00 \%$ of the variance in contact frequency with organizations, were identified through a factor analysis with a principal component extraction and varimax rotation. A frequency of contacts with a state wildlife agency (FRQ_CONT_STATE_WILD) served as a proxy variable for the factor including statelevel forest and wildlife organizations, conservation organizations, and the Extension service. A frequency of contacts with local agricultural co-ops (FRQ_CONT_AGRI) was selected as the proxy variable for a factor including agricultural organizations. Finally, a frequency of contacts with the U.S. Fish and Wildlife Service (FRQ_CONT_NAT_WILD) was selected as the proxy variable for a factor representing national-level forest and wildlife organizations, and land trusts.

Geospatial variables included proximity to environmental amenities measures as a distance to the nearest national park (DIST_NAT_PARK), state park (DIST_STA_PARK), and local park (DIST_LOC_PARK). Additionally, geospatial variables included a proximity to urban areas with population of 50,000 or more people (DIST_UA) and urbanized areas with a population of at least 2,500 but less than 50,000 (DIST_UC). In terms of land-use patterns, geospatial variables were added to represent a percentage change in grasslands/herbaceous land (CHANG_GRLANDS) and pasture/hay land (CHANG_PASLANDS) area during 1992-2011.

\subsection{Model Specification}

The CVM was used to determine grassland owner WTA for enrolling into a conservation program facilitating the provision of ecosystem services on their grasslands based on a theoretical framework referred as a consumer surplus measure. Consumer surplus can be differentiated into two components: a compensating variation (CV) and an 
equivalent variation (EV) (Kolstad 2000). In a case of proposed welfare gain due to a change in a public good, such as a grassland ecosystem service, the CV defines a monetary amount (i.e., portion of income) that an individual can give up to ensure availability of this good and still maintain her/his original utility level (i.e., WTP measure). The EV, on the other hand, defines the amount of monetary compensation needed to achieve the original utility level in a case when a provision of a public good is decreased (i.e., WTA measure). In a case of welfare loss, the CV indicates the level of income increase required by an individual to compensate her/him for experienced welfare loss and maintain the original utility level (i.e., WTA measure), whereas the EV defines the amount of income that an individual would need to sacrifice to avoid future loss (i.e., WTP measure, Venkatachalam 2004).

In the context of the proposed enrollment into a conservation program requiring landowners to implement grassland management restrictions, a landowner might experience a welfare loss due to land management restrictions and thus might require a monetary compensation to maintain her/his original utility level. Thus, the CV measure within this context can be used to determine potential welfare loss and estimate a monetary amount to compensate a landowner for implementing land management restrictions facilitating the provision of ecosystem services by enrolling into a grassland conservation program. 


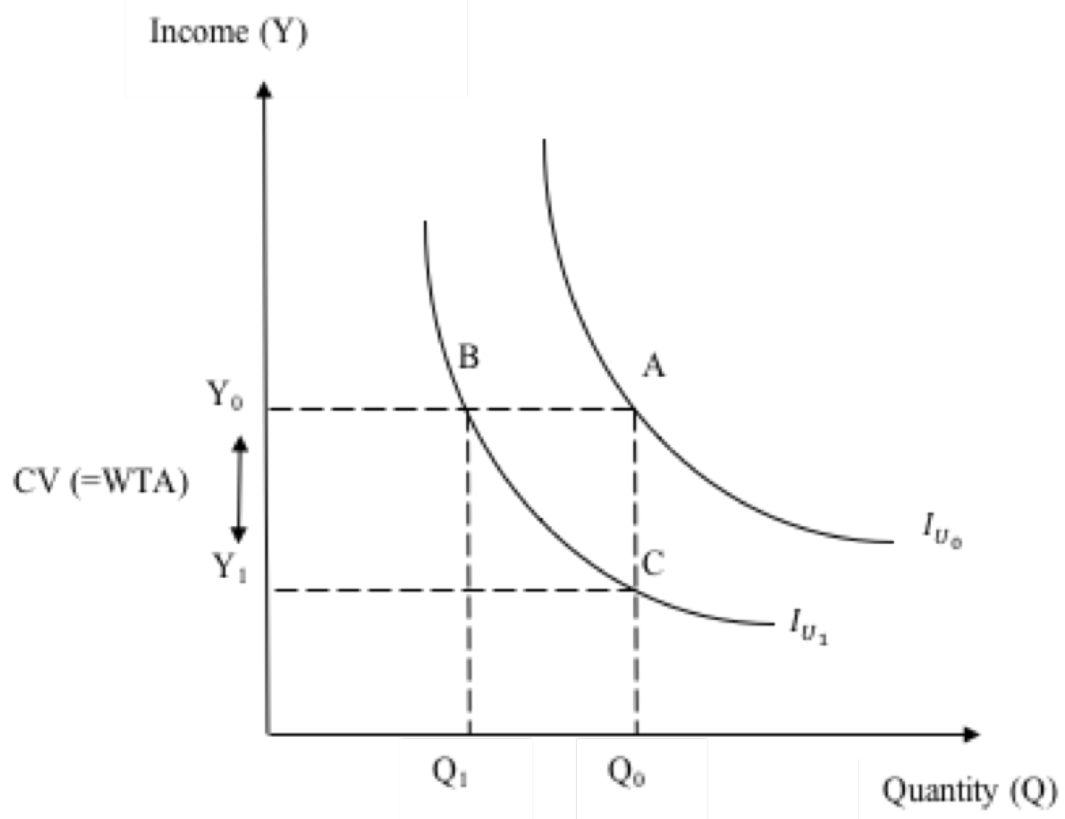

Figure 3.3 Compensating variation (CV) in a case of welfare loss incurred by a landowner who implemented grassland management restrictions required by a conservation program.

Figure 3.3 shows a graphical representation of CV where a vertical axis represents landowner's income $(Y)$ and horizontal axis denotes a level of freedom in implementing various land management practices $(Q)$. Suppose that initially a landowner has income of $Y_{0}$ and the corresponding quantity of freedom to manage land is $Q_{0}$. Thus, a landowner's original utility level of $U_{0}$ can be represented by point $\mathrm{A}$. Then, there is decrease in the quantity of freedom to land use from $Q_{0}$ to $Q_{1}$ due to management restrictions required by a proposed grassland conservation program. This changes the level of land management freedom from point $A$ to $B$ and landowner utility associated with this level changes from $U_{0}$ to $U_{1}$ where each indifference curve $\left(I_{U_{0}}\right.$ and $\left.I_{U_{I}}\right)$ shows the locus of points that provide a landowner with the same utility level. Therefore, $I_{U_{0}}$ is an 
indifference curve representing the utility level of $U_{0}$ for a status quo (before enrollment into a grassland conservation program) and $I_{U_{I}}$ is the indifference curve representing a lower utility level of $U_{l}$ after implementing land management restriction. Thus, the difference between income levels $Y_{l}$ and $Y_{0}$ represents $\mathrm{CV}$ because, at point $A$, if this income amount is taken away from the landowner, their utility level will move to the utility level of $U_{l}$ and the quantity of freedom to land use will return to a level represented by a point $C$. In this case, $\mathrm{CV}$ denotes a grassland landowner's minimum WTA amount that would be necessary to compensate her/him for a change in the quantity of freedom to use the land from $Q_{0}$ to $Q_{1}$.

Indirect utility and expenditure functions provide the basic theoretical structure in welfare economics (Haab and McConnell 2002). During the application of a stated preference technique, such as CVM, researchers assess changes in these utility and expenditure functions (Haab and McConnell 2002). Therefore, a random utility model was used to analyze binary choice stated preference responses to estimate coefficient parameters corresponding to the difference between two different utility levels associated with participation in a proposed grassland conservation program facilitating ecosystem services (Haab and McConnell 2002). The binary choice model setting represented two alternatives in which landowners voted "yes" or "no" for participation in the proposed grassland conservation program. Thus, the landowner indirect utility function was expressed as in Equation 3.1:

$$
U_{i j} f_{j}\left(Y_{i}, X_{i}, Z_{i}^{j}, \epsilon_{i j}\right)
$$


where $U$ is the $i^{\text {th }}$ landowner level of indirect utility, $j=1$ if a landowner was willing to participate in the proposed conservation program at an offered monetary compensation (bid) level, $j=0$ if the landowner was not willing to participate in the program (status quo), $Y_{i}$ is the $i^{\text {th }}$ landowner's income, $X_{i}$ stands for an m-dimensional vector of respondent characteristics, $Z_{i}^{j}$ is a vector of choice specific attributes (Table 3.1), and $\epsilon_{i j}$ is a preference component known by a landowner but not observed by a researcher.

A landowner will participate in the proposed grassland conservation program at an offered compensation level of $t_{i}$, if the utility associated with participation in the proposed program plus the monetary compensation, exceeds utility of the status quo (See Equation 3.2) (Haab and McConnell 2002):

$$
f_{1}\left(Y_{i}+t_{i}, X_{i}, Z_{i}^{1}, \epsilon_{i 1}\right)>f_{0}\left(Y_{i}, X_{i}, Z_{i}^{0}, \epsilon_{i 0}\right)
$$

However, a researcher does not know the random preference components and can only make probability statements about "yes" and "no" responses related to participation in the proposed grassland conservation program (Haab and McConnell 2002). Therefore, the probability that a landowner will participate in the program (a "yes" response) can be defined as the probability of landowner believing that that she/he is better off when agreeing to participate in the program at an offered compensation level $\left(U_{i 1}>U_{i 0}\right)$. The probability of participating in a proposed conservation program by the $i^{\text {th }}$ landowner can be defined as noted in Equation 3.3 (Haab and McConnell 2002):

$$
\operatorname{Pr}\left(\text { yes }_{i}\right)=\operatorname{Pr}\left(f_{l}\left(Y_{i}+t_{i}, X_{i}, Z_{i}^{1}, \epsilon_{i 1}\right)>f_{0}\left(Y_{i}, X_{i}, Z_{i}^{0}, \epsilon_{i 0}\right)\right)
$$

However, to estimate the model, it was necessary to identify deterministic ( $v)$ and random $(\varepsilon)$ parts in the indirect utility function, which can be expressed as Equation 3.4: 


$$
U_{i j=} f_{j}\left(Y_{i}, X_{i}, Z_{i}^{j}, \epsilon_{i j}\right)=v_{i j}\left(Y_{i}, X_{i}, Z_{i}^{j}\right)+\epsilon_{i j}
$$

Using the additive specification from Equation 4, the probability that $i^{\text {th }}$ landowner will participate in the proposed grassland conservation program can be written as noted in Equation 3.5:

$$
\operatorname{Pr}\left(\text { yes }_{i}\right)=\operatorname{Pr}\left(v_{l}\left(Y_{i}+t_{i}, X_{i}, Z_{i}^{1}, \epsilon_{i l}\right)>v_{0}\left(Y_{i}, X_{i}, Z_{i}^{0}, \epsilon_{i 0}\right)\right)
$$

and, the model can be further expanded as noted in Equation 3.6:

$$
\operatorname{Pr}\left(\text { yes }_{i}\right)=\operatorname{Pr}\left(v_{l}\left(Y_{i}+t_{i}, X_{i}, Z_{i}^{l}\right)-v_{0}\left(Y_{i}, X_{i}, Z_{i}^{0}\right)>\epsilon_{i 0}-\epsilon_{i 1}\right)
$$

When utility is specified as a sum of random and deterministic components, the difference in random components between status quo and participation in the conservation program cannot be identified. Therefore, the random part initially specified as $\epsilon_{i 0}-\epsilon_{i 1}$ can be expressed as noted in Equation 3.7:

$$
\epsilon_{i j}=\epsilon_{i 0}-\epsilon_{i 1}
$$

However, this probability specification is still too general for parameter estimation. Therefore, a more specific indirect utility function needs to be derived for estimating purposes. The linear indirect utility function was specified in Equation 3.8 (Haab and McConnell 2002):

$$
v_{j}\left(Y_{i}, X_{i}, Z_{i}^{j}\right)=\gamma_{j}+\beta_{j} Y_{i}+\alpha_{j} X_{i}+\delta_{j} Z_{i}^{j}
$$

Where $\beta_{j}, \alpha_{j}, \delta_{j}$ are m-dimensional vector parameters. Therefore, based on Equation 8 , the deterministic utility function associated with participation in the proposed conservation program (a "yes" vote; $j=1$ ) can be written as noted in Equation 3.9:

$$
v_{1}\left(Y_{i}+t_{i}, X_{i}, Z_{i}^{l}\right)=\gamma_{1}+\beta_{1}\left(Y_{i}+t_{i}\right)+\alpha_{1} X_{i}+\delta_{1} Z_{i}^{l}
$$


Similarly, a deterministic utility function for status quo where landowners were not willing to enroll in the conservation program ("no" vote; $j=0$ ) can be written as in Equation 3.10:

$$
v_{0}\left(Y_{i}, X_{i}, Z_{i}^{0}\right)=\gamma_{0}+\beta_{0} Y_{i}+\alpha_{0} X_{i}+\delta_{0} Z_{i}^{0}
$$

Thus, the deterministic utility change due to participation in the proposed grassland conservation program, assuming that $v_{i 1}>v_{i 0}$, can be specified as follows (Equation 3.11):

$$
v_{i l}-v_{i 0}=\left(\gamma_{1}-\gamma_{0}\right)+\left(\beta_{1}-\beta_{0}\right) Y_{i}+\beta_{1} t_{i}+\left(\alpha_{1}-\alpha_{0}\right) X_{i}+\delta_{1} Z_{i}^{l}-\delta_{0} Z_{i}^{0}
$$

A common assumption regarding parameters of variables that differ across utility levels is that they are equal (Haab and McConnell 2002). Thus, it can be assumed that the marginal utility of income and environmental good attributes between the two alternatives is constant, unless the proposed $\mathrm{CV}$ scenario provides a substantial change in their level of income or utility from participation in the grassland conservation program (Kim and Petrolia 2013). Hence, it can be stated that $\beta_{1} \cong \beta_{0}=\beta, \delta_{1} \cong \delta_{0}=\delta$. Consequently, a deterministic utility change due to participation in the proposed conservation program can be expressed as in Equation 3.12 where $\alpha_{1}-\alpha_{0}=\alpha, \gamma_{1}-\gamma_{0}=\gamma$ :

$$
v_{i 1}-v_{i 0}=\gamma+\beta Y+\beta_{1} t_{i}+\alpha X_{i}+\delta\left(Z_{i}^{l}-Z_{i}^{0}\right)
$$

Thus, the probability that a landowner will participate in the proposed grassland conservation program becomes as noted in Equation 3.13:

$$
\operatorname{Pr}\left(\text { yes }_{i}\right)=\operatorname{Pr}\left(\gamma+\beta Y+\beta_{1} t_{i}+\alpha X_{i}+\delta\left(Z_{i}^{l}-Z_{i}^{0}\right)\right)+\varepsilon_{i j}>0
$$

where $\epsilon_{i j}$ is defined as in Equation 3.7.

Built on economic theory and econometric model specification, a binary choice model was developed to conduct an econometric analysis. To estimate the parameters due 
utility change, it was necessary to specify the nature of random terms (Haab and McConnell 2002). Thus, the assumption was that the $\epsilon_{i j}$ are independently and identically distributed (IID) with a mean of zero. Given that the error is IID with a mean of zero, normal and logistic distributions have been widely used (Haab and McConnell 2002). The normal distribution for the difference $\varepsilon=\varepsilon_{1}-\varepsilon_{0}$ would result if $\varepsilon_{1}$ and $\varepsilon_{0}$ are each independent and normally distributed. The logistic distribution can be derived as the difference between two extreme value distributions. Both, the normal and logistic distributions, are symmetric, which facilitates model estimation by statistical software packages (Haab and McConnell 2002). Thus, the probability of "yes" response for $i^{\text {th }}$ landowner can be estimated as noted in Equations 3.14, 3.15, and 3.16:

$$
\begin{aligned}
\operatorname{Pr}\left(\left(\gamma+\beta Y+\beta_{1} t_{i}+\alpha X_{i}+\delta\left(Z_{i}^{l}-Z_{i}^{0}\right)\right)+\varepsilon_{i}>0\right) & =\operatorname{Pr}\left(-\left(\gamma+\beta Y+\beta_{1} t_{i}+\alpha X_{i}+\delta\left(Z_{i}^{l}-Z_{i}^{0}\right)\right)<\varepsilon_{i}\right) \\
& =1-\operatorname{Pr}\left(-\left(\gamma+\beta Y+\beta_{1} t_{i}+\alpha X_{i}+\delta\left(Z_{i}^{l}-Z_{i}^{0}\right)\right)>\varepsilon_{i}\right) \\
& =\operatorname{Pr}\left(\varepsilon_{i}<\gamma+\beta Y+\beta_{1} t_{i}+\alpha X_{i}+\delta\left(Z_{i}^{l}-Z_{i}^{0}\right)\right)
\end{aligned}
$$

The equality in Equation 3.16 exploits the symmetry of the distribution (Haab and McConnell 2002). For symmetric distributions where $F(x)=1-F(-x)$, suppose that $\varepsilon_{i} \sim \mathrm{N}$ $\left(0, \sigma^{2}\right)$, where $\sigma^{2}$ stands for variance in $\varepsilon_{i}$. If $\varepsilon_{i} \sim N(0, \sigma 2)$ is converted to a standard normal $[\mathrm{N}(0,1)]$ variable, and assuming that $\theta=\varepsilon / \sigma$, then $\theta \sim \mathrm{N}(0,1)$ (Haab and McConnell 2002) and the probability can be specified as follows (Equations 3.17 and 3.18):

$$
\begin{aligned}
\operatorname{Pr}\left(\varepsilon_{i}<\gamma+\beta Y+\beta_{1} t_{i}+\alpha X_{i}+\delta\left(Z_{i}^{l}-Z_{i}^{0}\right)\right) & =\operatorname{Pr}\left(\theta<\frac{\gamma+\beta Y+\beta_{1} t_{i}+\alpha X_{i}+\delta\left(Z_{i}^{l}-Z_{i}^{0}\right)}{\sigma}\right) \\
& =\Phi\left(\frac{\gamma+\beta Y+\beta_{1} t_{i}+\alpha X_{i}+\delta\left(Z_{i}^{l}-Z_{i}^{0}\right)}{\sigma}\right)
\end{aligned}
$$


where $\Phi(x)$ is the cumulative standard probability that a unit normal variable is less than or equal to $x$. This model is known as the probit model which represents the probability in terms of parameters divided by an unknown variance (Haab and McConnell 2002). This is a key characteristic of a dichotomous dependent variable where the parameter can only estimate up to a scaler multiple, because the dependent variable is taking a value of zero or one and has no scale (Haab and McConnell 2002).

WTA compensation was defined as a monetary amount that would make a landowner indifferent between the status quo and participation in the proposed grassland conservation program. Therefore, a difference between the two utility levels was implicitly defined as WTA (Haab and McConnell 2002). Thus, if WTA is replaced with variable $t_{i}$ from Equation 2 and $t_{i}$ is the (varying) compensation amount for the decrease in $Q$ (decreased freedom in implementing land management prescriptions due to participation in a conservation program), then, based on Equation 3.12 it can determined that Equation 3.19:

$$
v_{i 1}-v_{i 0}=\gamma+\beta Y+\beta_{1} W T A+\alpha X_{i}+\delta\left(Z_{i}^{1}-Z_{i}^{0}\right)
$$

The right-hand side of Equation 3.19 represents the econometric model where estimated the parameters were used to estimate WTA for enrollment in a grassland conservation program (Equation 3.20):

$$
\gamma_{1}+\beta_{1}\left(Y_{i}+W T A\right)+\alpha_{1} X_{i}+\delta_{1} Z_{i}^{l}+\epsilon_{i 1}=\gamma_{0}+\beta_{0} Y_{i}+\alpha_{0} X_{i}+\delta_{0} Z_{i}^{0}+\epsilon_{i 0}
$$

Thus, WTA can be expressed as in Equations 3.21 and 3.22:

$$
\begin{gathered}
W T A=-\frac{\left(\gamma_{I}-\gamma_{0}\right)}{\beta_{I}}-\frac{Y_{i}\left(\beta_{1}-\beta_{0}\right)}{\beta_{I}}-\frac{X_{i}\left(\alpha_{I}-\alpha_{0}\right)}{\beta_{I}}-\frac{\delta_{0}\left(Z_{i}^{I}-\delta_{I} Z_{i}^{0}\right)}{\beta_{I}}-\frac{\epsilon_{i j}}{\beta_{I}} \\
W T A=-\frac{\gamma}{\beta_{I}}-\frac{Y_{i} \beta_{0}}{\beta_{I}}-\frac{X_{i} \alpha}{\beta_{I}}-\frac{\delta\left(Z_{i}^{0}-Z_{i}^{l}\right)}{\beta_{I}}-\frac{\epsilon_{i j}}{\beta_{I}}
\end{gathered}
$$


Here, there are two sources of randomness (uncertainty from randomness of preference and parameters) and the potential for variation across individuals. If it is assumed that the parameters are given, the expected mean WTA with respect to preference uncertainty $(\varepsilon)$ is (Haab and McConnell, 2002, Equation 3.23):

$$
E_{\varepsilon}\left(W T P_{i} \mid \alpha, \beta, Z_{i}\right)=\frac{\alpha Z_{i}}{\beta}
$$

However, because the parameters are unknown, parameter uncertainty must be resolved. Thus, based on Slutsky's theorem on consistency, a consistent estimate of expected WTA was determined by substituting the normalized parameter estimated into the expression for expected WTA (Haab and McConnell 2002, Equation 3.24):

$$
E_{\varepsilon}\left(W T P_{i} \mid \alpha, \beta, Z_{i}\right)=[(\alpha / \sigma /(\beta / \sigma))] Z_{i}
$$

Therefore, a mean WTA was quantified by multiplying each coefficient (except that of a bid) by its sample mean and then divided by coefficient of the bid (Equation 20, Haab and McConnell 2002). 
Table 3.1 Description of the variables used in the probit model to estimate monetary compensation amounts for participation in a hypothetical grassland conservation program facilitating provision of ecosystem services.

\begin{tabular}{|c|c|}
\hline Variable name & Variable description \\
\hline \multicolumn{2}{|l|}{ Dependent variable } \\
\hline ENROLL & $\begin{array}{l}\text { Willingness to enroll in the proposed grassland } \\
\text { conservation program. Coded as a binary variable: } 1 \text { if } \\
\text { a landowner was willing to enroll in the program, } 0 \text { if } \\
\text { unwilling. }\end{array}$ \\
\hline \multicolumn{2}{|l|}{ Independent variables } \\
\hline BID & $\begin{array}{l}\text { An annual payment amount offered to a landowner for } \\
\text { enrolling in a 10-year grassland conservation program } \\
\text { (\$/acre/year). }\end{array}$ \\
\hline AGE & Landowner's age (years). \\
\hline GENDER & $\begin{array}{l}\text { Landowner's gender. Coded as a binary variable: } 1 \text { if } \\
\text { male, } 0 \text { if female. }\end{array}$ \\
\hline INCOME & $\begin{array}{l}\text { Landowner's household income before taxes in } 2014 \\
\text { (\$). }\end{array}$ \\
\hline AGLAND & $\begin{array}{l}\text { Area of agricultural land owned by a landowner } \\
\text { (acres). }\end{array}$ \\
\hline FORLAND & Area of forest land owned by a landowner (acres). \\
\hline OBJ_PRO_ENDANG ${ }^{\mathrm{a}}$ & $\begin{array}{l}\text { Ecosystem service landownership objective. Priority } \\
\text { of protecting endangered species as a landownership } \\
\text { objective. Coded as a binary variable: } 1 \text { if a priority, } 0 \\
\text { if not a priority. }\end{array}$ \\
\hline OBJ_PROFIT ${ }^{\mathrm{a}}$ & $\begin{array}{l}\text { Profit landownership objective. Priority of profitable } \\
\text { activities as a landownership objective. Coded as a } \\
\text { binary variable: } 1 \text { if a priority, } 0 \text { if not a priority. }\end{array}$ \\
\hline OBJ_FAMI_TRAD ${ }^{\mathrm{a}}$ & $\begin{array}{l}\text { Family tradition landownership objective. Priority of } \\
\text { family tradition as a landownership objective. Coded } \\
\text { as a binary variable: } 1 \text { if a priority, } 0 \text { : if not a priority. }\end{array}$ \\
\hline OBJ_REC_INV ${ }^{\mathrm{a}}$ & $\begin{array}{l}\text { Recreational and long-term investment based } \\
\text { landownership objectives. Priority of fee-based } \\
\text { recreational activities and long-term investment as a } \\
\text { landownership objective. Coded as a binary variable: } \\
1 \text { if priority, } 0 \text { if not a priority. }\end{array}$ \\
\hline FRQ_CONT_STATE_WILD ${ }^{\mathrm{b}}$ & $\begin{array}{l}\text { Frequency of contacts with state-level forest and } \\
\text { wildlife organizations, conservation organizations, } \\
\text { and Extension. Frequency of landowner contacts with } \\
\text { state-level forest and wildlife organizations, } \\
\text { conservation organizations, and Extension. Coded as a } \\
\text { binary variable: } 1 \text { if frequently, } 0 \text { if not frequently. }\end{array}$ \\
\hline
\end{tabular}


Table 3.1 (continued)

\begin{tabular}{|c|c|}
\hline Variable name & Variable description \\
\hline FRQ_CONT_AGRI $^{b}$ & $\begin{array}{l}\text { Frequency of contacts with agricultural organizations. } \\
\text { Frequency of landowner contacts with local agriculture } \\
\text { co-ops, farm service agency, farm bureau or farmers' } \\
\text { association of landowners. Coded as a binary variable: } 1 \\
\text { if frequently, } 0 \text { if not frequently. }\end{array}$ \\
\hline FRQ_CONT_NAT_WILD ${ }^{\mathrm{b}}$ & $\begin{array}{l}\text { Frequency of contacts with national-level forest and } \\
\text { wildlife organizations and land trusts. Frequency of } \\
\text { landowner contacts with U.S. Fish and Wildlife Service, } \\
\text { U.S. Forest Service, and land trusts. Coded as a binary } \\
\text { variable: } 1 \text { if frequently } 0 \text { if not frequently. }\end{array}$ \\
\hline DIST_NAT_PARKS & Distance to the nearest national park (miles). \\
\hline DIST_STA_PARKS & Distance to the nearest state park (miles). \\
\hline DIST_LOC_PARKS & Distance to the nearest local park (miles). \\
\hline DIST_UA & $\begin{array}{l}\text { Distance to the nearest urbanized area with population of } \\
50,000 \text { or more (miles). }\end{array}$ \\
\hline DIST_UC & $\begin{array}{l}\text { Distance to the nearest urban cluster with a population of } \\
\text { at least 2,500 and less than 50,000 (miles). }\end{array}$ \\
\hline CHANG_GRLANDS & $\begin{array}{l}\text { A percentage change in grassland/herbaceous land area } \\
\text { during 1992-2006. }\end{array}$ \\
\hline CHANG_PASLANDS & $\begin{array}{l}\text { A percentage change in pasture/hay land area during } \\
1992-2006 .\end{array}$ \\
\hline
\end{tabular}

${ }^{\mathrm{a}}$ Landowner priority in landowning objectives were originally recorded as categorical variables ranked on a rising 1-5 Likert scale. The original five Likert scale categories were recoded into a binary variable based on the mean rank value. Original rank values higher than a mean were recoded to 1 a (priority) and values smaller than a mean were recoded to 0 (not a priority).

${ }^{\mathrm{b}}$ Landowner contact frequency with organizations to obtain technical or financial assistance. Originally recorded as a categorical variable measured on a rising 1-5 Likert rank scale and then recoded to a binary variable based on the mean rank value. The original five Likert scale categories were recoded into a binary variable based on the mean rank value. Original rank values higher than a mean were recoded to 1 (frequently) and values smaller than a mean were recoded to 0 (not frequently). 


\section{CHAPTER IV}

\section{RESULTS}

\subsection{Landowner socio-demographic characteristics}

The adjusted survey response rate was comparable with other studies surveying landowners conducted by Grala et al. (2012), Gruchy et al. (2012), and Amigues et al. (2002). Sample socio-demographic factors such as age, gender, forest land area, education, and household income were consistent with the socio-economic characteristics of states covered by the Interior Highland region as reported in National Woodland Owner Survey (NWOS, NWOS 2011-2013, Butler et al. 2016), where it indicated that most landowners were male, in their 50s or $60 \mathrm{~s}$, with an average of 62.00 acres of forest land, and having an undergraduate education. The average area of agricultural land owned by sampled landowners was larger $(p<0.05)$ than the forest land they owned indicating that the sampled landowners were more involved in agricultural production compared to forestry.

Of 2,000 questionnaires mailed, 476 were returned of which 242 were completed and useable for analysis reflecting an adjusted response rate of $33.00 \%$. The non-response bias test indicated that there was no difference between the survey results and parameter 
estimates found in the NWOS in terms of age, gender, education level, and forest land area owned $(p>0.05)$. In contrast, the nonresponse bias test based on statistics reported in the USDA Census of Agriculture (USDA, National Agricultural Statistics Service 2012) indicated that there were differences in terms of age, gender and agricultural area owned $(p<0.05)$. These results indicated that the sample consisted of older landowners, mostly male, and who owned smaller area of agricultural lands compatred to socio-demographic characteristics reported in the USDA Census of Agriculture.

Most landowners were males and accounted for $83.12 \%$ of landowners, whereas female landowners were $16.93 \%$. In general, $65.30 \%$ of landowners were above 60 years of age with an average age of 63 years. In terms of education, $49.24 \%$ of landowners obtained a two-year college degree or higher education, $21.90 \%$ attended some college, $27.70 \%$ completed high school or took general educational development tests, and $1.20 \%$ did not complete high school. The mean annual gross household income before taxes in 2014 was US\$78,801 where 38.80\% reported income less than U\$55,000 and $61.25 \%$ reported income greater than US\$55,000 which was greater than the mean U.S. household income of US\$ 3,657 for 2014 (U.S. Census Bureau 2014).

In terms of landowner affiliation with organizations, only $5.80 \%$ of landowners were members of state- or county-level forest and wildlife organizations, whereas $13.32 \%$ of landowners were members of conservation or environmental organizations or community service organizations. Meanwhile, $21.54 \%$ of landowners were members of state or county agriculture or farm-based organizations. The majority of landowners (59.10\%) did not belong any organization (Table 4.1). 
Table 4.1 Landowner membership in organizations based on responses to a mail survey conducted in 2016 in the Interior Highlands geographic area of Gulf Coastal Plain and Ozarks Land Conservation Cooperative, United States.

\begin{tabular}{lc}
\hline Organization type & Percentage (\%) \\
\hline State-wide forestry organization & 0.40 \\
State-wide wildfire organization & 3.30 \\
County forestry organization & 0.40 \\
County wildlife organization & 2.90 \\
State-wide agriculture or farm-based organization & 13.20 \\
County agriculture or farm-based organization & 15.30 \\
Conservation or environmental organization & 8.30 \\
Community service organization & 7.00 \\
None & 59.10 \\
Other & 5.00 \\
\hline
\end{tabular}

In terms of landowner contact frequency with organizations to obtain technical or financial assistance, the most frequently contacted organizations, based on a rising 1-5 ranking Likert scale, included county/university Extension service (mean ranking $=2.2$ ), followed by USDA NRCS (mean ranking =1.9). Land trusts were the least frequently organization contacted by landowners (mean ranking $=1.2$ ) (Table 4.2). The Friedman ranking implied that landowner contact frequency between organizations was different $\left(\chi^{2}=463.7, p<0.00\right)$. 
Table 4.2 Landowner contact frequency with organizations providing technical and financial assistance based on responses to a mail survey conducted in 2016 in the Interior Highlands geographic area of Gulf Coastal Plain and Ozarks Land Conservation Cooperative, United States.

\begin{tabular}{lc}
\hline Organization providing technical and financial assistance & Mean ranking \\
\hline County/university Extension services & 2.20 \\
State forestry agency & 1.60 \\
State wildlife agency & 1.74 \\
Farm Bureau or Farmers Association & 1.80 \\
Local agricultural co-ops (not a farmer association) & 1.75 \\
Local conservation groups & 1.58 \\
State or national conservation groups & 1.52 \\
USDA Natural Resource Conservation Services & 1.93 \\
Farm Service Agency & 1.92 \\
U.S. Forest Service & 1.37 \\
U.S. Fish and Wildlife Services & 1.38 \\
Land trusts & 1.23 \\
Other & 1.94 \\
\hline Rank sele:1-N
\end{tabular}

Rank scale: 1 - Never, 2 - Seldom, 3 - About half of the time, 4 - Often, 5 - Always.

\subsection{Land ownership characteristics}

The mean landownership size was 205.54 acres where an average size of forest and agricultural lands was 72.20 and 133.60 acres, respectively. Landowner reasons for owning these lands varied substantially as indicated by Friedman ranking test $\left(\chi^{2}=\right.$, 1016.8, $p<0.00$ ). Based on a rising 1-5 Likert rank scale, the provision of ecosystem services such as wildlife habitat was the primary reason (3.7), followed by a legacy to heirs and long term investment (3.4). The lowest-priority reason was the provision of feebased recreation (1.2). Reasons for landownership related to profitable working land for traditional forest, rangeland, and agricultural products such as pulpwood, crops, livestock, non-traditional products such as nuts and fruits, and organic ranching were assigned medium to low priority rankings ranging from 3.03 to 2.24 (Table 4.3 ). 
Table 4.3 Priority of reasons for landownership based on responses to a mail survey conducted in 2016 in the Interior Highlands geographic area of Gulf Coastal Plain and Ozarks Land Conservation Cooperative, United States.

\begin{tabular}{lc}
\hline Landowner reasons for owning land & Mean ranking \\
\hline $\begin{array}{l}\text { Profitable working land for traditional forest, rangeland, and } \\
\text { agricultural products (e.g., saw logs, pulpwood, crops, livestock) }\end{array}$ & 3.03 \\
Profitable working land for non-traditional forest, rangeland, and & \\
agricultural products (e.g., nuts and fruits; forage and shelter for & 2.24 \\
livestock, organic ranching, recreation) & \\
Personal recreation for myself, family members, and friends & 3.42 \\
Fee-based recreation & 1.27 \\
Long-term investment & 3.42 \\
Family tradition & 3.37 \\
Providing a legacy to heirs & 3.49 \\
Maintaining healthy soils & 3.63 \\
Providing clean water & 3.62 \\
Maintaining wildlife habitat & 3.71 \\
Protecting endangered species & 2.90 \\
Sequestering carbon & 2.09 \\
Maintaining visually appealing land appearance & 3.41 \\
Other & 3.39 \\
\hline
\end{tabular}

Rank scale: 1 - Not priority, 2 - Low priority, 3 - Medium priority, 4 - High priority, 5 - Essential.

\subsection{Concern with environmental issues}

Most landowners were highly concerned about drinking water quality and quantity which received mean rankings of 4.18 and 3.90 on a 1-5 Likert scale, respectively. Landowners were also concerned with environmental issues related to intensive agriculture such as loss of wildlife habitat (3.8), soil erosion (3.7), loss of natural areas and other open spaces (3.6), and threat of invasive species (3.4). Finally, landowners were relatively less concerned with water quality (3.0) and quantity (2.9) for recreational activities as well as water quality (2.0) and quantity (2.0) for crop irrigation (Table 4.4). The Friedman ranking test result was significant $\left(\chi^{\wedge 2}=108.0, p<0.00\right)$, implying that concern on each environmental issue was ranked differently by landowners. 
Table 4.4 Landowner concern with environmental issues based on responses to a mail survey conducted in 2016 in the Interior Highlands geographic area of Gulf Coastal Plain and Ozarks Land Conservation Cooperative, United States.

\begin{tabular}{lc}
\hline Environmental issue & Mean ranking \\
\hline Water-related issues & \\
Drinking water quality & 4.18 \\
Drinking water quantity & 3.90 \\
Water quality for crop irrigation & 2.03 \\
Water quantity for crop irrigation & 2.07 \\
Water quality for recreation (e.g., swimming, boating, fishing) & 3.05 \\
Water quantity for recreation e.g., swimming, boating, fishing) & 2.96 \\
Intensive agriculture-related issues & \\
Chemical drift & 3.19 \\
Invasive species & 3.42 \\
Soil erosion & 3.71 \\
Overgrazing & 2.82 \\
Loss of forest land & 3.38 \\
Loss of farm lands, natural areas, other open spaces & 3.64 \\
Loss of wildlife habitat & 3.80 \\
Loss of pollinators & 3.70 \\
Other & \\
Wildfire & 3.09 \\
Insect pests & 3.42 \\
Animal pests & 3.12 \\
Hurricanes and tornadoes & 2.78 \\
\hline Rank scale: 1 - Not priority at all, 2-Slightly concerned, 3 - Somewhat concerned, 4- Moderately \\
concerned, 5 - Extremely concerned.
\end{tabular}

\subsection{Satisfaction towards existing financial and technical assistance programs}

Majority of landowners (70.23\%) were unsatisfied or neither satisfied nor unsatisfied with financial assistance programs, whereas $29.82 \%$ were satisfied. The most satisfactory financial assistance program, based on a rising 1 to 5 Likert rank scale, was the Conservation Reserve Program (CRP, 3.0), followed by the Environmental Quality Incentives Program (EQIP, 2.8). Significant results of Friedman ranking test $\left(\chi^{\wedge^{2}}=\right.$ 1217.5, $\mathrm{p}<0.00$ ) indicated that the level of satisfaction towards each existing financial assistance program was ranked differently by landowners. 
In terms of technical assistance programs, $67.34 \%$ of landowners were not satisfied or neither satisfied nor unsatisfied with the existing technical assistance programs, while $32.72 \%$ of landowners were satisfied. Moreover, the Friedman ranking test was significant $\left(\chi^{\wedge^{2}}=56.5, p<0.00\right)$, implying that the level of satisfaction with regard to each existing technical assistance program was ranked differently by landowners. The most satisfactory technical assistance program, based on a rising 1 to 5 Likert rank scale, was the Conservation Technical Assistance (CTA, 3.1), followed by the Forest Stewardship Program (FSP, 2.8).

\subsection{Determinants of willingness to accept compensation}

The estimated model (Pseudo $\left.\mathrm{R}^{2}=0.21, \mathrm{AIC}=267.52\right)$ showed that landowner socio-demographic characteristics including income and age were associated with the probability of enrolling in the conservation program $(p<0.10)$. An increment in income by $\$ 1,000.00$ translated to an increased probability that a landowner will enroll in the conservation program by $0.10 \%$ (Table 4.5 ). Similarly, a one year increase in landowner age related to a $0.30 \%$ decrease in enrollment probability (Table 4.5 ). The level of monetary compensation offered to landowners was positively associated with enrollment probability $(\mathrm{p}<0.01)$. The marginal effect of compensation level was 0.001 , indicating that a for a $\$ 1$ increase in a compensation level, the probability of enrolling into a conservation program increased by $0.10 \%$. (Table 4.5 ). However, other sociodemographic variables, including gender, education level, and area of owned agricultural and forest land, did not have a relationship with enrollment probability $(\mathrm{p}>0.10$, Table 4.5). 
Variables representing the priority of ecosystem services, profit, family tradition, and recreational or long-term investment in landownership were not related with the probability of enrolling into a conservation program ( $p>0.10$, Table 4.5$)$. However, landowner membership in organizations, and frequency of contact with state wildlife agencies was positively associated with enrollment probability $(p<0.05)$ where landowners who contacted state wildlife agencies frequently for technical and financial assistance were $13.40 \%$ more likely to enroll than landowners who contacted these agencies not frequently. However, a contact frequency with local agriculture co-ops and the U.S. Fish and Wildlife Service was not related with enrollment probability $(p>0.10$, Table 5).

Among variables representing spatial attributes, proximity to the nearest local park was associated with the probability that a landowner will enroll into the conservation program. A one mile increase in distance to a local park was related to an enrollment probability decrease of $0.40 \%(p<0.01$, Table 4.5$)$ meaning that landowners in proximity of local parks were more likely to enroll. However, proximity to the nearest state and national parks did not have a relationship with enrollment probability $(p>0.10$, Table 4.5). Similarly, proximity to urban areas and clusters was not related to enrollment probability ( $p>0.10$, Table 4.5$)$. In terms of land-use changes during 1992-2011, a percentage change in grassland/herbaceous land area was related to enrollment probability and a landowner owning land in an area which experienced a $1.00 \%$ increase in grassland/herbaceous land area was $0.10 \%$ more likely to enroll $(p<0.1$, Table 4.5$)$. However, a change in pasture/hay land area was not associated with enrollment probability $(p>0.10$, Table 4.5$)$. 
Landowners showed a higher tendency for enrolling in the conservation program at higher compensation levels. For example, there were only $7.60 \%$ of the landowners who agreed to enroll in the conservation program at a payment of $\$ 1$ per acre per year, whereas $81.23 \%$ of landowners were willing to enroll in the same conservation program at the payment of $\$ 320$ per acre per year. However, based on estimated model parameters, a mean WTA amount required by landowners to enroll in the proposed grassland conservation program involving a 10 -year contract was $\$ 290.10$ per acre per year. Lower and upper WTA bounds estimated for the $95 \%$ confidence interval were $\$ 174.50$ per acre per year and $\$ 407.60$ per acre per year, respectively (Table 4.5). 
Table 4.5 Factors associated with landowner willingness to enroll in a conservation program based on responses to a mail survey conducted in 2016 in the Interior Highlands geographic area of Gulf Coastal Plain and Ozarks Land Conservation Cooperative, United States.

\begin{tabular}{lccc}
\hline Variable & Coef. & S.E. & M.E. \\
\hline BID & $0.003^{* * *}$ & 0.000 & 0.001 \\
AGE & $-0.011^{*}$ & 0.008 & -0.003 \\
GENDER & -0.107 & 0.259 & -0.028 \\
INCOME & $0.005^{*}$ & 0.003 & 0.001 \\
AGLAND & -0.000 & 0.000 & -0.000 \\
FORLAND & -0.000 & 0.001 & -0.000 \\
OBJ_ENDANG & 0.118 & 0.221 & 0.033 \\
OBJ_PROFIT & -0.237 & 0.228 & -0.066 \\
OBJ_FAMI_TRAD & -0.139 & 0.230 & -0.039 \\
OBJ_REC_INV & 0.354 & 0.389 & 0.099 \\
FRQ_CONT_STATE_WILD & $0.477^{* *}$ & 0.227 & 0.134 \\
FRQ_CONT_AGRI & 0.236 & 0.235 & 0.066 \\
FRQ_CONT_NAT_WILD & -0.006 & 0.265 & -0.001 \\
DIST_NAT_PARKS & 0.001 & 0.004 & 0.000 \\
DIST_STA_PARKS & 0.011 & 0.012 & 0.003 \\
DIST_LOC_PARKS & $-0.023^{* * * *}$ & 0.009 & -0.006 \\
DIST_UA & -0.006 & 0.005 & -0.001 \\
DIST_UC & -0.007 & 0.016 & -0.002 \\
CHANG_GRLANDS & $0.000^{*}$ & 0.000 & 0.001 \\
CHANG_PASLANDS & -0.001 & 0.005 & -0.000 \\
Constant & -0.159 & 0.885 & \\
\hline Log likelihood & -112.76 & & \\
P-value & & & \\
N & 0.000 & & \\
*** Significant at a 1\% level; **Significant at a 5\% level; *Significant at a 10\% level; Coef.: Coefficient; \\
S.E.: Standard Error; M.E.; Marginal Effect. & &
\end{tabular}




\section{CHAPTER V DISCUSSION}

Grasslands have been increasingly converted to intensive cropping practices in the United States and it can be assumed that this conversion trend will continue into the future due to low profitability of the ranching industry and increased land demand for other uses (Conner et al. 2001). Collectively, these conversion trends have shifted grassland use from traditional ranching practices based on native grass species, such as wild free-range and managed grazing with domestic livestock, to modern grazing regimes utilizing introduced grass species, crop production, and other land uses. Thus, grasslands have been degraded and fragmented into smaller land parcels incapable of supporting original levels of ecosystem services such as wildlife habitat, carbon sequestration, water supply, and scenic beauty (Conner et al. 2001). These ecosystem services represent goods and benefits that have direct and indirect impacts on human well-being by sustaining biodiversity, providing clean water, ameliorating weather, and cycling nutrients. Therefore, actions are needed to limit the conversion of grassland ecosystems to other land uses and ensure availability of grassland ecosystem services for future generatio 
The important factor in facilitating preservation and sustainability of grassland ecosystem services is a quantification of their monetary value. Estimates of monetary values associated with grassland ecosystem services will provide valuable quantitative information to various stakeholders, such as decision-makers, federal and state conservation planners, and government and non-government conservation organizations that will facilitate a more effective implementation of conservation efforts in grassland ecosystems (Butler 2008). These stakeholders can use information on monetary values of ecosystem services to determine benefits and costs associated with preserving grassland ecosystems and determine future budgets for implementing various grassland conservation scenarios (Buttoud 2000).

Even though the literature on WTA estimates related specifically to grassland ecosystems is limited, this study's mean WTA of US\$290.10 per acre per year was relatively larger than estimates from similar studies that focused on landowner willingness to manage forests and wetlands for ecosystem services ( $\mathrm{Yu}$ and Belcher 2011, Kilgore et al. 2008, Kline et al. 2000a). For example, Kilgore et al. (2008) concluded that Minnesota landowners were willing to enroll in the Sustainable Forest Initiative (SFI) at a minimum payment of US\$24.00 per acre per year for an 8-year contract period. Kline et al. (2000b) indicated that a mean incentive payment required by U.S. forest landowners in the Pacific Northwest to forego a harvest in a riparian buffer varied between $\$ 38.00$ and $\$ 137.00$ per acre per year during a 10-year contract period, depending on landowner forest ownership objectives and socio-economic characteristics. Similarly, Yu \& Belcher (2011) noted that compensation required to induce landowners in Saskatchewan, Canada to implement wetland and riparian management strategies by 
placing riparian zones on their lands was US $\$ 31.00$ per acre for 10 years. Furthermore, there have been many studies implemented to quantify costs incurred by agricultural producers and landowners by implementing conservation practices in different parts of the world. For example, Kingsbury and Boggess (1999) reported that the minimum WTA required by Oregon landowners for enrolling their ranching and irrigated crop lands into the Conservation Reserve Enhancement Program (CREP) was $\$ 145.00$ and $\$ 205.00$ per acre per year, respectively. Similarly, a study by Amigues et al. (2002) determined that landowners in south-central France, who enrolled in crop production, required US $\$ 96.00$ per acre to preserve a 33-164 feet wide riparian strip. The required compensation was consistent with revenues that would be generated by crop production on a preserved riparian land strip.

Overall, previous research efforts have indicated that landowner WTA for implementing conservation practices on agricultural land was highly correlated with the opportunity cost representing forgone revenues when implementing such practices. Moreover, a compensation level required by landowners was influenced by a wide range of factors including a region's biophysical characteristics, agricultural land productivity, farm features, and landowner experience with conservation programs and their perception of environmental issues (Kingsbury and Boggess 1999, Heimlich et al. 1998). Therefore, a comparatively larger average compensation required by grassland owners in this study might be attributed to a higher profitability associated with implementing alternative land uses such as agricultural crop production (USDA ERS 2017).

Average payments for all sign-up types offered by the CRP varied from US $\$ 34.00$ to US\$107.00 per acre per year, depending on the state (USDA FSA 2016). Based on 
these CRP payment amounts, an average payment amount for the six states in the Interior Highland region was approximately US\$78.00 per acre per year. However, the average CRP payment in the Interior Highland region for a sign-up type called "Grasslands," and defined as enrollment in practices supporting grazing operations as well as preserving and restoring grasslands, was US\$25.00 per acre per year (USDA FSA 2017). Thus, the estimated compensation required by landowners within the Interior Highland region to enroll their grasslands into a proposed conservation program was four to 12 times larger than the average payment offered by CRP. These data indicated that compensation levels higher than current CRP payments might be necessary to induce landowners to enroll their lands in a grassland conservation program and achieve long-term conservation objectives. Therefore, at the current CRP payments levels, most of landowners might not be willing to enroll in a conservation program due to low payments even though they owned eligible lands (Suter et al. 2008, USDA NRCS 2014). For example, as of July 2017, there were no lands registered under CRP's grassland sign-up in the states of Arkansas and Illinois despite their extensive grassland cover (USDA FSA 2017). This trend might be caused by limited budgets and consequently lower payment levels offered to landowners (USDA FSA 2017). Therefore, a valuation of grassland ecosystem services is essential to determining appropriate budgets and adequate payment levels to enroll a sufficient area of grasslands into conservation programs and ensure future availability of ecosystem services.

Based on this study's WTA estimates and the total area of 10.90 million acres of grassland and pasture lands in the Interior Highland region (NLCD 2011), the total economic cost of preserving ecosystem services from grassland ecosystems was 
estimated at almost US\$3.00 billion per year. The estimated cost of this amount was 57 times larger than the 2016 CRP budget allocation of US $\$ 50.00$ million for 0.48 million acres in the Interior Highland region. However most existing grassland ecosystems in the region have been heavily influenced by the introduction of invasive or non-native plant species and intensive agricultural practices that resulted in a loss of their potential to provide the original level of ecosystem services, and thus they might no longer be suitable for restoration and preservation (Conner et al. 2001). Therefore, it is likely the total area of ecologically restorable grassland ecosystems is substantially smaller. Consequently, grassland conservation efforts might have to focus on priority grassland ecosystems by restoring and preserving ecosystems with high ecological value that will be crucial in achieving long-term conservation goals and feasible enough to achieve within existing budget constraints.

Grasslands within Interior Highlands have been categorized based on the presence of native plants, cover area treshold, disturbance patterns, and four attributes of ecologically feasible grasslands according to USGS ScienceBase-Catalog (GCPO LCC 2016). The four ecological attributes of grasslands included vegetation height greater than 3.28 feet (ft), herbaceous vegetation cover greater than $80 \%$, shrub cover smaller than $20 \%$, and tree density less than 10 trees per acre. Based on these data, there were 3.90 million acres of grasslands and prairie lands that had at least one attribute of ecologically feasible grasslands. Similarly, there were 1.00 million acres of grasslands and prairies with at least two attributes of ecologically feasible grasslands and only 5,996.80 acres of grasslands and prairies with three attributes of ecologically feasible grasslands. Based on these statistics, the total cost of preserving ecosystem services from grassland and prairie 
ecosystems that have at least one attribute was estimated at $\$ 1.30$ billion per year, whereas it was $\$ 0.30$ billion per year for grasslands and prairies characterized with at least two attributes. Similarly, the estimated budget necessary to preserve ecosystem services from grassland and prairie ecosystems with three attributes was only $\$ 1.74$ million per year. While the costs of preserving lands with more attributes of ecologically feasible grasslands seemed relatively smaller in comparison to lands with less attributes, it was due to a smaller total area of grasslands with high ecological value. Thus, in a case of limited budgets, future grassland conservation efforts might have to prioritize lands with a larger number of ecologically feasible grasslands and then as more funds are available include lands with smaller number of ecological attributes.

An informed budget allocation for conservation practices should also incorporate taxpayer opinions to ensure public funds are spent consistently with taxpayer conservation priorities. In terms of grassland ecosystem service values to the public, Dissanayake and Ando (2014) estimated that average household WTP for restoration of 100 acres of grassland in Illinois varied from $\$ 75.00$ to $\$ 150.00$ per year depending on proximity to a restored grassland. Based on these WTP estimates, a total public value of grasslands in the study area varied between US $\$ 8.18$ million to US $\$ 16.35$ million per year. However, WTP estimates developed by Dahal (2017) for preserving open spaces, which are comparable to grassland ecosystems, varied from $\$ 81.00$ to $\$ 162.00$ per household. Based on these estimates of open space public value, the total one-time WTP for preserving grassland ecosystems in the Interior Highlands region was estimated at US\$193.00 million to $\$ 389.00$ million. 
Landowner income levels had a positive relationship with the probability of participating in the proposed grassland conservation program where landowners with higher incomes were more likely to enroll. This finding was consistent with the previous findings of Layton and Siikamäki (2009) which indicated that landowners whose nonforest income was relatively high were more likely to enroll in a conservation program. Majority of landowners (61.20\%) in the study area had an annual household income above $\$ 55,000$ which was higher than a mean 2014 household income in the U.S. (US Census Bureau 2015). Thus, landowners with higher income might be more likely participate in a grassland conservation program facilitating increased production of ecosystem services.

Model results also indicated that landowner age had a negative relationship with program enrollment probability where older landowners were less likely to enroll. Findings related to age were consistent with findings of Konyar and Osborne (1990) who reported that older landowners were less willing to attempt new and non-traditional management strategies and thus were less likely to enroll in new conservation programs compared to younger landowners. The influence of landowner age on participation in conservation efforts is not clear because, some studies claimed that landowner age had no influence on enrollment in conservation programs (Zhang and Flick 2001, Thacher et al. 1997). However, this study's results implied that younger landowners were more willing to participate in a grassland conservation program. This finding has important implications because the majority of landowners were in an older age class indicating that large land areas will transfer ownership to younger generations of landowners and their cooperation will be crucial for attaining long-term grassland conservation objectives. 
Younger landowners might require new and innovative outreach approaches, such as flexible online training and workshops that will fit landowner schedules and require a dissemination of information via e-mails and blogs.

The monetary compensation level offered to landowners was positively associated with the probability of enrollment indicating that the likelihood of implementing conservation practices in grassland ecosystems increased with higher compensation amounts. This finding is consistent with previous research in the context of ecosystem monetary valuation conducted by Broch et al. (2013), Sorice et al. (2011), Yu and Belcher (2011), Kilgore et al. (2008), and who indicated that higher monetary compensation levels would induce more landowners to commit their lands to conservation efforts. Therefore, it is important to utilize these findings during the development of direct incentive programs for grassland conservation strategies in the Interior Highlands as well as other regions with substantial areas of native grasslands.

Frequency of landowner contacts with state wildlife agencies was positively associated with enrollment probability, indicating that landowners who frequently contacted state wildlife agencies were more likely to enroll in a conservation program when compared to those landowners who did not contact a state wildlife agency frequently. This finding could be linked to the effect of outreach programs focused on Extension, public education, and management conducted by most state wildlife agencies (McCleery et al. 2014). Therefore, landowners interacting with state wildlife agencies might be more educated on environmental issues and consequently more willing to enroll in conservation programs. Thus, developing programs and policies in collaboration with state wildlife agencies and distributing information on existing programs through these 
agencies might provide an effective outlet for reaching a larger number of landowners, increase their awareness of available technical and financial assistance opportunities, and improve overall effectiveness of, and participation in, future conservation programs.

Distance to a local park was associated with enrollment probability where landowners owning land in proximity to a local park were more likely to enroll. This result can be explained by the impact of landowners' limited property rights on their land use decisions due to neighboring parks (Colchester 2004, Ghimire and Pimbert 1997) and the legal protection of lands around protected areas (Pfaff et al. 2009, Nelson et al. 2001). These studies indicated that there would be a significant loss of forest cover if these limited property rights and legal protections were removed. Therefore, landowners who are close to local parks and forests may have a greater interest in alternative ways of utilizing their land such as implementing protective measures through conservation programs. Therefore, it is important to understand how protected areas influence landowners' land-use decisions and their willingness to participate in conservation efforts.

Landowners in areas that experienced an increase in grassland/herbaceous land cover were more likely to enroll in the grassland conservation program. These findings may be linked to the agricultural land abandonment due to ecological drivers (e.g., soil erosion, climate), socio-economic drivers (e.g., market incentives, technology), and improper land management (e.g., soil degradation, overexploitation, productivity loss) (Benayas et al. 2007). Lands abandoned due to a declining agricultural productivity (Müller and Zeller 2002, MacDonald et al. 2000, Rudel et al. 2000, Baldock et al. 1996), abandoned pasturelands, lands with steep slopes and poor soils or underdeveloped road 
infrastructure have been overgrown with trees and bushes (Kobler et al. 2005, RomeroCalcerrada and Perry 2004, Kozak 2003, MacDonald et al. 2000). Therefore, from a global perspective, abandonment of agricultural land has become one of the most important land-use changes (Ramankutty and Foley 1999). For example, in the eastern United States, most cropland, pasture lands, and other cleared lands were abandoned in the $19^{\text {th }}$ and early $20^{\text {th }}$ centuries (Kauppi et al. 2006, Houghton and Hackler 2000). Areas of cultivated crop lands and forest lands in the Interior Highland region have been substantially altered from 1992 to 2011 by 8.90 and 0.54 million acres, respectively (NLCD 1992, 2011). However, land-use decisions related to private lands have been critically dependent on land quality determined by expected economic returns from alternative land uses and related land-use policies (Lubowski et al. 2008). Meanwhile, few studies found that croplands in the U.S. has declined during the past two decades due to decreasing returns from crop production and the existence of CRP (Vesterby and Krupa 1995, Alig et al. 1998). For example, Lubowski et al. (2008) determined that without CRP and the Wetland Reserve Program (WRP) croplands would have increased by $2.00 \%$ in 1997 . Therefore, historical land-use patterns and potential land-use changes due to market conditions are important spatial factors to be considered during development of conservation programs as landowners might be more willing to enroll their abandoned lands due to relatively low opportunity costs.

Even though landowners' choice of enrolling in the conservation program was affected by the proximity to a local park, distance to the nearest state and national parks did not have any relationship $(p>0.10)$ with enrollment probability. Similarly, changes in pasture/hayland areas did not display a relationship with enrollment probability. 
Landowner proximity to the nearest urban area or cluster was also not related to landowner decisions to enroll in a conservation program. This finding could be attributed to relatively few landowners within the sample who were relatively close to an urban area or cluster. For example, more than $75.00 \%$ of landowner landownerships were more than 6 miles from urban area or cluster. Furthermore, all measures related to spatial attributes were based on an approximation of landowners' land location determined by postal code area centroid rather than an exact land location, which might have affected the precision of model estimates. Thus, more accurate information on land parcel location would facilitate more precise model estimates.

Different stakeholders including ecologists, conservation biologists, policy makers, conservation planners, and conservation program administrators need information on values derived from grassland ecosystem services and landowner preferences towards implementation of conservation practices to determine budgets and payment levels for specific practices to facilitate more effective grassland conservation. A better understanding of landowner conservation preferences and required compensation levels will be helpful in determining how and where to implement ecological restoration of grasslands and other ecosystems not only in the Interior Highlands but also in other parts of the United State and internationally. Information on monetary values related to grassland ecosystem services will enable quantification of tradeoffs between different levels of grassland conservation, cost of implementing conservation practices, and corresponding increases in ecosystem service production. 


\section{CHAPTER VI CONCLUSION AND POLICY IMPLICATIONS}

This study analyzed landowner willingness to participate in a grassland conservation program facilitating the provision of ecosystem services and quantifying monetary compensation required by landowners to participate in such a program. The study produced several findings that have implications in terms of grassland conservation planning and prioritization of conservation activities when budgets are limited. Results will help address growing concerns related to protecting and restoring native grasslands, ensure the future provision of grassland ecosystem services, determine budgets needed to achieve specific conservation objectives, and identify the most efficient and financially feasible conservation strategies.

Findings indicated that minimum and maximum compensation levels required by landowners to enroll their land into a grassland conservation program was US\$174.00 per acre per year and $\$ 408.00$ per acre per year, respectively, with a mean value of US\$290.10 per acre per year. Based on the estimated monetary values and area of grassland and pastureland classified by National Land Cover Data (Homer et al. 2015) within the Interior Highland region, the total cost of grassland ecosystem service preservation ranged from US $\$ 1.70$ to $\$ 4.10$ billion per year (2015 dollars). Thus, the 
average budget required to preserve all grassland ecosystems by sustainable land management practices in the region amounted US $\$ 2.90$ billion per year. However, with a selective screening process of existing grasslands that are characterized by the preferred ecological attributes, the total cost would vary from US $\$ 1.70$ million to $\$ 1.30$ billion depending upon the level of ecological attributes associated with potentially restorable grasslands within the Interior Highland region.

Landowner age, household income, and frequency of contacts with state wildlife agencies were related to the probability of enrollment into a grassland conservation program promoting ecosystem services. This information can also be used to identify landowners potentially willing to participate in conservation efforts and develop more effective conservation strategies. Additionally, conservation planners can use these results to identify trade-offs between grassland conservation scenarios providing differing levels of ecosystem services.

These facts are especially important in regions such as Interior Highlands that are dominated by privately owned prairie lands that potentially can be restored to ecologically potential grasslands by implementing sustainable management practices and increasing the provision of ecologically, economically, and socially important ecosystem services. However, future research should focus on quantifying the public WTP for ecosystem services from grasslands to help identify efficient budget allocations that will balance public demand for ecosystem services with land potential to produce them and prioritize conservation efforts accordingly. 


\section{REFERENCES}

Adger, W., Brown, K., Raffaello Cervigni, and Moran, D. (1995). Total economic value of forests in Mexico. Ambio, 24(5), 286-296.

Agnew, W., Uresk, D., and Hansen, R. (1986). Flora and fauna associated with prairie dog colonies and adjacent ungrazed mixed-grass prairie in Western South Dakota. Journal of Range Management, 39(2), 135-139.

Alig Ralph J., Dicks Michael R., Moulton Robert J.. 1998. "Land-use dynamics involving forestland: Trends in the U.S. South." In Proceedings of the 1988 Southern Forest Economics Workers Meeting, ed. Kluender R. A., Smith N. B., Corrigan M. M., pp. 9-23. Moticello, Ark: University of Arkansas.

Allen-Diaz, B., Chapin, F. S., Diaz, S., Howden, M., Puigdefábregas, J., and Stafford Smith, M. (1995). Rangelands in a changing climate: impacts, adaptations, and mitigation. Climate Change, pp. 131-158.

Amigues, J. P., Boulatoff, C., Desaigues, B., Gauthier, C., and Keith, J. E. (2002). The benefits and costs of riparian analysis habitat preservation: a willingness to accept/willingness to pay contingent valuation approach. Ecological Economics, 43(1), 17-31.

Armstrong, D. M., Choate, J. R., and Jones, J. K. (1986). Distributional patterns of mammals in the plains states. Texas Tech University Press, 105,1-27.

Arrow, K., Solow, R., Portney, P. R., Leamer, E. E., Radner, R., and Schuman, H. (1993). Report of the NOAA panel on contingent valuation. Federal Register, 58(10), 4601-4614.

Baldock, D., Beaufoy, G., Brouwer, F., and Godeschalk (1996). Farming at the margins: abandonment or redeployment of agricultural land in Europe. Institute for European Environmental Policy, London/The Hague.

Baker, B. W., Augustine, D. J., Sedgwick, J. A., and Lubow, B. C. (2013). Ecosystem engineering varies spatially: a test of the vegetation modification paradigm for prairie dogs. Ecography, 36(2), 230-239.

Bateman, I., Munro, A., Rhodes, B., Starmer, C., and Sugden, R. (1997). Does partwhole bias exist? An experimental investigation. The Economic Journal, 107(441), 322-332. 
Batt, B. D., Anderson, M. G., Anderson, C. D., and Caswell, F. D. (1989). The use of prairie potholes by North American ducks. Northern Prairie Wetlands, pp. 204227.

Benayas, J. R., Martins, A., Nicolau, J. M., and Schulz, J. J. (2007). Abandonment of agricultural land: an overview of drivers and consequences. CAB Reviews: Perspectives in Agriculture, Veterinary Science, Nutrition and Natural Resources, 2(57), 1-14.

Benedict, R. A., Freeman, P. W., and Genoway, H. H. (1996). Prairie legaciesMammals. In Sampson, F. B. and F. L. Knopf, editors. eds. Prairie Conservation. Island Press. Washington, DC., pp. 149-166.

Bibby, C. J., Crosby, N. J., Heath, M. J., Imboden, M. F., Johnson, C., Long, T. H., and AJ Thirgood, S. J. (1992). Putting biodiversity on the map: priority areas for global conservation (No. 333.95 P993). International Council for Bird Preservation, Cambridge (RU).

Bowles, S. (1998). Endogenous preferences: The cultural consequences of markets and other economic institutions. Journal of Economic Literature, 36(1), 75-111.

Boxall, P. C., Adamowicz, W. L., Swait, J., Williams, M., and Louviere, J. (1996). A comparison of stated preference methods for environmental valuation. Ecological Economics, 18(3), 243-253.

Boyer, T., and Polasky, S. (2004). Valuing urban wetlands: a review of non-market valuation studies. Wetlands, 24(4), 744-755.

Broch, S. W., Strange, N., Jacobsen, J. B., and Wilson, K. A. (2013). Farmers' willingness to provide ecosystem services and effects of their spatial distribution. Ecological Economics, 92, 78-86.

Brookshire, D. S., Eubanks, L. S., and Randall, A. (1983). Estimating option prices and existence values for wildlife resources. Land Economics, 59(1), 1-15.

Butler, B. J. (2008). Family forest owners of the United States, 2006. Gen. Tech. Rep. NRS-27.: USDA, Forest Service, Northern Research Station, Newtown Square, PA No.73. Accessed 19 September 2017.

Butler, B., Hewes, J. H., Dickinson, B. J., Andrejczyk, K., Butler, S. M., and MarkowskiLindsay, M. (2016). USDA Forest Service National Woodland Owner Survey: national, regional, and state statistics for family forest and woodland ownerships with 10+ acres, 2011-2013. Accessed 19 September 2017. 
Buttoud, G. (2000). How can policy take into consideration the "full value" of forests? Land Use Policy, 17(3), 169-175.

Carr, L., and Mendelsohn, R. (2003). Valuing coral reefs: a travel cost analysis of the Great Barrier Reef. AMBIO: A Journal of the Human Environment, 32(5), 353357.

Carson, R. T., Flores, N. E., and Meade, N. F. (2001). Contingent valuation: controversies and evidence. Environmental and Resource Economics, 19(2), 173210.

Carson, R. T., Mitchell, R. C., Hanemann, M., Kopp, R. J., Presser, S., and Ruud, P. A. (2003). Contingent valuation and lost passive use: damages from the Exxon Valdez oil spill. Environmental and Resource Economics, 25(3), 257-286.

Choe, K., Whittington, D., and Lauria, D. (1996). The Economic Benefits of Surface Water Quality Improvements in Developing Countries: A Case Study of Davao, Philippines. Land Economics,72(4), 519-537.

Ciriacy-Wantrup, S. V. (1947). Capital returns from soil-conservation practices. Journal of Farm Economics, 29(4), 1181-1196.

Clawson, M. (1959). Methods of measuring the demand for and value of outdoor recreation. Resources for the future, Washington DC.

Colchester, M. (2004). Conservation policy and indigenous peoples. Environmental Science \& Policy, 7(3), 145-153.

Conner, R., Seidl, A., VanTassell, L., and Wilkins, N. (2001). United States grasslands and related resources: an economic and biological trends assessment. Texas A\&M University, Institute of Renewable Natural Resources. Accessed 19 September 2017.

Corn, P. S., and Peterson, C. R. (1996). Prairie legacies-amphibians and reptiles. In F.B. Samson and F.L. Knopf, eds. Prairie conservation: preserving North America's most endangered ecosystem, pp. 125-135, Island Press, Covelo, CA.

Costello, A. B., and Osborne, J. W. (2005). Best practices in exploratory factor analysis: Four recommendations for getting the most from your analysis. Practical Assessment, Research \& Evaluation, 10(7), 1-9.

Coupland, R. T. (1958). The effects of fluctuations in weather upon the grasslands of the Great Plains. The Botanical Review, 24(5), 273. 
Cowardin, L. M., Sargeant, A. B., and Duebbert, H. F. (1983). Problems and potentials for prairie ducks. Naturalist, 34(4), 4-11.

Cummings, R.G., Brookshire, D.S., Schultze W.D. (Eds.), 1986. Valuing Environmental Goods: A State of the Arts Assessment of the Contingent Method. Roman and Allanheld, Totowa, NJ.

Davis, R. K. (1963). Recreation planning as an economic problem. Natural Resources Journal, 3(2), 239-249.

DeFries, R. S., Field, C. B., Fung, I., Collatz, G. J., and Bounoua, L. (1999). Combining satellite data and biogeochemical models to estimate global effects of humaninduced land cover change on carbon emissions and primary productivity. Global Biogeochemical Cycles, 13(3), 803-815.

Deng, X., Huang, J., Rozelle, S., and Uchida, E. (2006). Cultivated land conversion and potential agricultural productivity in China. Land Use Policy, 23(4), 372-384.

Desvousges, W. H., Reed Johnson, F., Dunford, R. W., Nicole Wilson, K., and Boyle, K. J. (1993). Measuring natural resource damages with contingent valuation. In Contingent valuation: a critical assessment, pp. 91-164. Emerald Group Publishing Limited, Amsterdam: North- Holland.

Dillman, D. A. (2007). Mail and Internet surveys: The tailored design method (second ed.), Hoboken, John Wiley Co., New Jersey.

Dissanayake, S. T., and Ando, A. W. (2014). Valuing grassland restoration: proximity to substitutes and trade-offs among conservation attributes. Land Economics, 90(2), 237-259.

Dolisca, F., Carter, D. R., McDaniel, J. M., Shannon, D. A., and Jolly, C. M. (2006). Factors influencing farmers' participation in forestry management programs: A case study from Haiti. Forest Ecology and Management, 236(2), 324-331.

Duffield, J. (1997). Nonmarket valuation and the courts: the case of the Exxon Valdez. Contemporary Economic Policy, 15(4), 98-110.

Earnhart, D. (2006). Using contingent-pricing analysis to value open space and its duration at residential locations. Land Economics, 82(1), 17-35.

Egbert, S., Lauver, C., Blodgett, C., Price, K., and Martinko, E. (1997). Mapping the Kansas grasslands: a multiseasonal approach. Gap Analysis Bulletin, 6,12-13.

Farber, S. C., Costanza, R., and Wilson, M. A. (2002). Economic and ecological concepts for valuing ecosystem services. Ecological economics, 41(3), 375-392. 
Fletcher Jr, R. J., and Koford, R. R. (2002). Habitat and landscape associations of breeding birds in native and restored grasslands. The Journal of Wildlife Management, pp. 1011-1022.

Freeman, A. M. (1993). Nonuse values in natural resource damage assessment. Valuing natural assets: the economics of natural resource damage assessment, pp. 264303.

Freeman III, A. M., Herriges, J. A., and Kling, C. L. (2014). The measurement of environmental and resource values: theory and methods. Resources for the Future, Washington, DC.

Fry, J. A., Coan, M. J., Homer, C. G., Meyer, D. K., and Wickham, J. D. (2009). Completion of the National Land Cover Database (NLCD) 1992-2001 land cover change retrofit product. Open-File Report 2008-1379. Denver: U.S. Geological Survey, p. 18.

Gee, C. K., Joyce, L. A., and Madsen, A. G. (1992). Factors affecting the demand for grazed forage in the United States. General technical report RM (USA).

Ghimire, K. B., and Pimbert, M. P. (1997). Social change and conservation: an overview of issues and concepts. Social change and conservation: Environmental politics and impacts of national parks and protected areas, Earthscan Publications, pp. 145, London.

Grala, R. K., Tyndall, J. C., and Mize, C. W. (2012). Willingness to pay for aesthetics associated with field windbreaks in Iowa, United States. Landscape and Urban Planning, 108(2), 71-78.

Gregersen, H. M. (1995). Valuing forests: context, issues and guidelines. Food \& Agriculture Org. Forestry Paper, Vol. 127, Rome.

Gruchy, S. R., Grebner, D. L., Munn, I. A., Joshi, O., and Hussain, A. (2012). An assessment of nonindustrial private forest landowner willingness to harvest woody biomass in support of bioenergy production in Mississippi: a contingent rating approach. Forest Policy and Economics, 15, 140-145.

Haab, T. C., and McConnell, K. E. (2002). Valuing environmental and natural resources: the econometrics of non-market valuation. Edward Elgar Publishing Limited. Cheltenham, UK.

Hanley, N. S., Shogren, J. F., and White, B. (2002). Environmental economics in theory and practice (No. 333.7 H241). Palgrave Macmillan, England. 
Hardy, M. A. (1993). Regression with dummy variables . Sage, (Vol. 93), Thousand Oaks, CA.

Hatch, D. A., Bartolome, J. W., Fehmi, J. S., and Hillyard, D. S. (1999). Effects of burning and grazing on a coastal California grassland. Restoration Ecology, 7(4), 376-381.

Heimlich, R. E., Wiebe, K. D., Claassen, R., Gadsby, D., and House, R. M. (1998). Wetlands and agriculture: Private interests and public benefits. Agricultural Economics Report, 765, p. 104.

Homer, C.G., Dewitz, J.A., Yang, L., Jin, S., Danielson, P., Xian, G., Coulston, J., Herold, N.D., Wickham, J.D., and Megown, K. 2015. Completion of the 2011 National Land Cover Database for the conterminous United States-Representing a decade of land cover change information. Photogrammetric Engineering and Remote Sensing, 81(5), 345-354.

Horne, P., and Petäjistö, L. (2003). Preferences for alternative moose management regimes among Finnish landowners: A choice experiment approach. Land Economics, 79(4), 472-482.

Inman, K., and McLeod, D. M. (2002). Property rights and public interests: A Wyoming agricultural lands study. Growth and Change, 33(1), 91-114.

Kilgore, M. A., Snyder, S. A., Schertz, J., and Taff, S. J. (2008). What does it take to get family forest owners to enroll in a forest stewardship-type program? Forest Policy and Economics, 10(7), 507-514.

Kim, T. G., and Petrolia, D. R. (2013). Public perceptions of wetland restoration benefits in Louisiana. ICES Journal of Marine Science, 70(5), 1045-1054.

Kingsbury, L., and Boggess, W. (1999). Economic Analysis of Riparian Landowner's Willingness to Participate in Oregon's Conservation Reserve Enhancement Program. Selected paper for the annual meeting of the Agricultural Economics Association, p. 15, August 8-11, Nashville, Tennessee.

Kline, J. D., Alig, R. J., and Johnson, R. L. (2000a). Forest owner incentives to protect riparian habitat. Ecological Economics, 33(1), 29-43.

Kline, D., Alig, J., and Johnson, L. (2000b). Fostering the production of nontimber services among forest owners with heterogeneous objectives. Forest Science, 46(2), 302-311. 
Knopf, F. L. (1995). Declining grasslands birds, in LaRoe, T., G. S. Farris, C. E. Puckett, D. P. Doran, and J. M. Mac, editors. (eds.). Our Living Resources: A Report to the Nation on the Distribution, Abundance and Health of US Plants, Animals, and Ecosystems United States Department of the Interior, pp. 296-298, National Biological Service, Washington, DC.

Kobler, A., Cunder, T., and Pirnat, J. (2005). Modelling spontaneous afforestation in Postojna area, Slovenia. Journal for Nature Conservation, 13(2), 127-135.

Kolstad, C. (2000). Environmental Economics ,p. 400, Oxford University Press, New York, Oxford.

Kong, F., Yin, H., and Nakagoshi, N. (2007). Using GIS and landscape metrics in the hedonic price modeling of the amenity value of urban green space: A case study in Jinan City, China. Landscape and urban planning, 79(3), 240-252.

Konyar, K., and Osborn, C. T. (1990). A national-level economic analysis of conservation reserve program participation: a discrete choice approach. The Journal of Agricultural Economics Research, 42(2), 5-12.

Kozak, J. (2003). Forest cover change in the western Carpathians in the past 180 years: A case study in the Orawa region in Poland. Mountain Research and Development, 23(4), 369-375.

Krishna, J. H., Arnold, J. G., and Richardson, C. W. (1988). Modeling agricultural, forest and rangeland hydrology. In Proceedings of the 1988 Symposium. American Society of Agricultural Engineers Publication, pp. 07-88.

Kuchler, A. W. (1975). Potential Natural Vegetation of the Conterminous United States, American Geographical Society: New York.

Lauenroth, W. K. (1979). Grassland primary production: North American grasslands in perspective. Perspectives in grassland ecology: results and applications of the US/IBP grassland biome study, pp. 3-24.

Layton, D. F., and Siikamäki, J. (2009). Payments for ecosystem services programs: predicting landowner enrollment and opportunity cost using a beta-binomial model. Environmental and Resource Economics, 44(3), 415-439.

Lehtonen, E., Kuuluvainen, J., Pouta, E., Rekola, M., and Li, C. Z. (2003). Non-market benefits of forest conservation in southern Finland. Environmental Science \& Policy, 6(3), 195-204. 
Lieth, H. (1975). Modeling the primary productivity of the world. In Primary productivity of the biosphere, pp. 237-263. Springer: Berlin, Heidelberg.

Licht, D. S. (1997). Ecology and economics of the Great Plains (Vol. 10). U of Nebraska Press, Lincoln.

Loomis, J., and DuVair, P. H. (1993). Evaluating the effect of alternative risk communication devices on willingness to pay: results from a dichotomous choice contingent valuation experiment. Land Economics, pp. 287-298.

Loomis, J., and Ekstrand, E. (1997). Economic benefits of critical habitat for the Mexican spotted owl: a scope test using a multiple-bounded contingent valuation survey. Journal of Agricultural and Resource Economics, pp. 356-366.

Loomis, J., Kent, P., Strange, L., Fausch, K., and Covich, A. (2000a). Measuring the total economic value of restoring ecosystem services in an impaired river basin: results from a contingent valuation survey. Ecological Economics, 33(1), 103-117.

Loomis, J., Rameker, V., and Seidl, A. (2000b). Potential non-market benefits of Colorado's agricultural lands: a review of the literature. Land use and planning report. Colorado State University. Dept. of Agricultural and Resource Economics; LUPR 00-02. February.

Lubowski, R. N., Plantinga, A. J., and Stavins, R. N. (2008). What drives land-use change in the United States? A national analysis of landowner decisions. Land Economics, 84(4), 529-550.

MacDonald, D., Crabtree, J. R., Wiesinger, G., Dax, T., Stamou, N., Fleury, P., Lazpita G., and Gibon, A. (2000). Agricultural abandonment in mountain areas of Europe: environmental consequences and policy response. Journal of Environmental Management, 59(1), 47-69.

Matthews, E., Payne, R., Rohweder, M., and Murray, S. (2000). Pilot analysis of global ecosystems: forest ecosystems. World Resources Institute, Washington DC.

Martin, L. M., and Wilsey, B. J. (2006). Assessing grassland restoration success: relative roles of seed additions and native ungulate activities. Journal of Applied Ecology, 43(6), 1098-1109.

McCleery, R. A., Moorman, C. E., and Peterson, M. N. (Eds.). (2014). Urban wildlife conservation: theory and practice. Springer, New York.

Miller, B., Ceballos, G., and Reading, R. (1994). The prairie dog and biotic diversity. Conservation Biology, 8(3), 677-681. 
Mitchell, R. C., and Carson, R. T. (1989). Using surveys to value public goods: the contingent valuation method. Resources for the Future, Washington DC.

Muller, D., and Zeller, M. (2002). Land use dynamics in the central highlands of Vietnam: a spatial model combining village survey data with satellite imagery interpretation. Agricultural Economics, 27(3), 333-354.

Munn, I. A., Hussain, A., Spurlock, S., and Henderson, J. E. (2010). Economic impact of fishing, hunting, and wildlife-associated recreation expenditures on the southeast US regional economy: an input-output analysis. Human Dimensions of Wildlife, 15(6), 433-449.

Natural Resources Conservation Service (NRCS), U. (1997). National range and pasture handbook. Washington, DC: USDA NRCS.

Neill, H. R., Cummings, R. G., Ganderton, P. T., Harrison, G. W., and McGuckin, T. (1994). Hypothetical surveys and real economic commitments. Land Economics, pp. 145-154.

Nelson, G. C., Harris, V., Stone, S. W., Barbier, E. B., and Burgess, J. C. (2001). Deforestation, land use, and property rights: empirical evidence from Darien, Panama. Land Economics, 77(2), 187-205.

Niklitschek, M., and León, J. (1996). Combining intended demand and yes/no responses in the estimation of contingent valuation models. Journal of Environmental Economics and Management, 31(3), 387-402.

Omernik, J. M. (1987). Ecoregions of the conterminous United States. Annals of the Association of American Geographers, 77(1), 118-125.

Packard, S., and Mutel, C. F. (1997). The Tallgrass Restoration Handbook: For Prairies. Savannas and Woodlands.

Pfaff, A., Robalino, J., Sanchez-Azofeifa, G. A., Andam, K. S., and Ferraro, P. J. (2009). Park location affects forest protection: Land characteristics cause differences in park impacts across Costa Rica. The BE Journal of Economic Analysis \& Policy, 9(2).

Power, T. M. (1996). Lost landscapes and failed economies: The search for a value of place. Island Press, Washington DC.

Ramankutty, N., and Foley, J. A. (1999). Estimating historical changes in global land cover: Croplands from 1700 to 1992. Global Biogeochemical Cycles, 13(4), 9971027. 
Rashford, B. S., Walker, J. A., and Bastian, C. T. (2011). Economics of grassland conversion to cropland in the Prairie Pothole Region. Conservation Biology, 25(2), 276-284.

Reynolds, R. (2005). The Conservation Reserve Program and Duck Product ion in the US Prairie Pothole Region. In J. B. Haufler, editor. Fish and wildlife benefits of Farm Bill conservation programs: 2000-2005 update. The Wildlife Society Technical Review 05-2, pp. 33-40. Bethesda, Maryland, USA.

Ricketts, T. H., E. Dinerstein, D. M. Olson, C. J. Loucks, W. Eichbaum, D. DellaSala, K. Kavanagh, P. Hedao, P. T. Hurley, K. M. Carney, R. Abell, and S. Walters. 1999. Terrestrial Ecoregions of North America: A Conservation Assessment. Island Press. 1, p. 485, Washington DC.

Ridker, R. G., \& Henning, J. A. (1967). The determinants of residential property values with special reference to air pollution. The Review of Economics and Statistics, pp. 246-257.

Romero-Calcerrada, R., and Perry, G. L. (2004). The role of land abandonment in landscape dynamics in the SPA 'Encinares del río Alberche y Cofio, Central Spain, 1984-1999. Landscape and Urban Planning, 66(4), 217-232.

Rudel, T. K., Perez-Lugo, M., and Zichal, H. (2000). When fields revert to forest: development and spontaneous reforestation in post-war Puerto Rico. The Professional Geographer, 52(3), 386-397.

Rudzitis, G. (1993). Nonmetropolitan geography: migration, sense of place, and the American West. Urban Geography, 14(6), 574-585.

Sala, O. E., and Paruelo, J. M. (1997). Ecosystem services in grasslands. Nature's services: societal dependence on natural ecosystems, pp. 237-251, Island Press, Washington, DC, USA.

Samson, F. B., and Knopf, F. L. (Eds.). (1996). Prairie conservation: preserving North America's most endangered ecosystem. Island Press, Washington DC and Covello, California, USA.

Smith, V. K. (1993). Nonmarket valuation of environmental resources: an interpretive appraisal. Land Economics, pp. 1-26.

Shelford, V. E. (1963). The Ecology of North America. The ecology of North America. University of Illinois Press, Chicago, p. 722.

Sneath, D. (1998). State policy and pasture degradation in Inner Asia. Science, 281, pp. 1147-1148. 
Solbrig OT (1993) Ecological constraints to savanna land use. In Young MD, Solbring OT (eds) The world's savannas. Parthenon, Paris, pp. 21-48

Sorice, M. G., Haider, W., Conner, J. R., and Ditton, R. B. (2011). Incentive structure of and private landowner participation in an endangered species conservation program. Conservation Biology, 25(3), 587-596.

Stoddart, L. A., and Smith, A. D. (1955). Range management. Range Management., No. Ed. 2, McGraw-Hill Book Company Inc., New York; Toronto ; London.

Suter, J. F., Poe, G. L., and Bills, N. L. (2008). Do landowners respond to land retirement incentives? Evidence from the conservation reserve enhancement program. Land Economics, 84(1), 17-30.

Swinton, S. M., Lupi, F., Robertson, G. P., and Hamilton, S. K. (2007). Ecosystem services and agriculture: cultivating agricultural ecosystems for diverse benefits. Ecological Economics 64, 245-252.

Thacher, T., Lee, D. R., and Schelhas, J. W. (1996). Farmer participation in reforestation incentive programs in Costa Rica. Agroforestry Systems, 35(3), 269-289.

Tyrväinen, L., and Miettinen, A. (2000). Property prices and urban forest amenities. Journal of environmental Economics and Management, 39(2), 205-223.

Venkatachalam, L. (2004). The contingent valuation method: a review. Environmental Impact Assessment Review, 24(1), 89-124.

Vesterby, M., and Krupa, K. S. (2001). Major uses of land in the United States, 1997. Washington DC: Resource Economics Division, Economic Research Service, USDA. Statistical Bulletin No. 973.

White, R. P., Murray, S., Rohweder, M., Prince, S. D., and Thompson, K. M. (2000). Grassland ecosystems, p. 81. World Resources Institute, Washington, DC.

Zhang, D., and Flick, W. A. (2001). Sticks, carrots, and reforestation investment. Land Economics, 77(3), 443-456.

Walsh, R. G., Loomis, J. B., and Gillman, R. A. (1984). Valuing option, existence, and bequest demands for wilderness. Land Economics, 60(1), 14-29.

Woodward, R. T., and Wui, Y. S. (2001). The economic value of wetland services: a meta-analysis. Ecological Economics, 37(2), 257-270. 
Yu, J., and Belcher, K. (2011). An economic analysis of landowners' willingness to adopt wetland and riparian conservation management. Canadian Journal of Agricultural Economics/Revue canadienne d'agroeconomie, 59(2), 207-222.

Economic Research Service, US Department of Agriculture (USDA ERS, 2000). Washington DC, USA. Retrieved on September 26, 2017, from http://www.ers.usda.gov/costsandreturns/.

Economic Research Service, US Department of Agriculture (USDA ERS, 2017). Washington DC, USA. Retrieved on September 26, 2017, from http://www.ers.usda.gov/costsandreturns/.

Gulf coastal plains and Ozarks landscape conservation cooperative - Development and operational plans. (2009). Retrieved on September 23, 2017, from http://gcpolcc.org/.

Stoddart, L. A., and Smith, A. D. (1955). Range management, (Edition 2), pp.vii-433 New York Mcgraw-Hill Book Company Inc. New York.

US Geological Survey (USGS). (2000). Water science for schools. Retrieved on September 26, 2017, from http://ga.water.usgss.gov/edu/tables/maptotals.

U.S. Department of Interior and U.S. Department of Commerce (USDI and USDC). 2012. 2011 National Survey of Fishing, Hunting, and WildlifeAssociated Recreation, National Overview. U.S. Dept. of Interior, Fish and Wildlife Service and U.S. Dept. of Commerce, Bureau of Census. U.S. Government Printing Office, Washington, DC, USA. Retrieved on September 20, 2017, from https://www.census.gov/prod/www/fishing.html.

U.S. Census Bureau (2014) American community survey. Retrieved on September 20, 2017, from https://www.census.gov/programs-surveys/acs/news/datareleases/2014.html.

US Department of Agriculture, Farm Service Agency (USDA FSA). 2016. Retrieved on September 26, 2017, from https://www.fsa.usda.gov/.

US Department of Agriculture, Farm Service Agency (USDA FSA). 2017. Retrieved on September 20, 2017, from https://www.fsa.usda.gov/. 